\title{
A Study on Socio- Educational and Rehabilitation Status of Street Children in Kolkata.
}

\author{
Chiranjit Mukherjee \\ Assistant Professor of R.K.V.M. (Sarada Ma Girls'College).
}

\section{Introduction}

In spite of India's economic boom - for much of the population the situation has not improved through generations. Hundreds of millions are trapped by caste and gender discrimination, and by the cycle of:

Poverty -> Child labor -> No education ->Poverty

These people endure some of the worst conditions experienced anywhere in the world. An Indian child is more likely to be malnourished, have inadequate sanitation, do not attend school and remain illiterate, marry underage, than a child from Africa or any other in the globe. The number of children with or without family, migrating to the harsh reality of street life, is increasing. Rural-urban migration was one of the important reasons for children to move on the street life. Rural-urban migration of adults as well as children happened mostly due to flood and other natural disasters, which has been considered as a major cause of their fast growth (Deshingkar and Grimm, 2005; Afsar, 2000; Begum, 1999; Ahmed and Jasimuddin, 1996). The causes for migration can be divided into two main aspects, the so-called "push" and "pull" factors. Push factors are those which force people in their old place to move. Pull factors are factors which encourage people in the target city to move. The migration of children from their homes to life on the streets is a global issue. Rural to urban migration may include: entire families, men alone, or children (orphan, abandoned etc.).

Some of these migrated children spend their childhood years working and living on the streets, and have no opportunities to play or schooling. Many live with their families in some of the poorest sections of the metropolitan cities. Some street children live with families for purely economic reasons.

So, Street Children are, In the strict sense: lives, earns, eats and breeds on the street .In the wider sense: has no home and lives on the street with family. In the widest sense: has a home but uses the street to earn and exist (Indian National NGO Forum for street / working children,1990) According to "UNICEF" 'street children' are those for whom the street (in the widest sense of the word, i.e. unoccupied dwellings, wastelands etc.) more than their family has become their real home, a situation in which there is no protection, supervision, or direction from responsible adults.'

"Street children" may be categorized as:

1) "children on the streets," or those who are engaged in some street trade and usually return at night to some shelter;

2) "children of the streets," who voluntarily seek shelter, companionship, and livelihood on the streets; and 3) "abandoned children," who survive entirely on their own with no ties to families.

Globally UNICEF reported: 'The latest estimates put the numbers of these children as high as 100 million. It is likely that the numbers are increasing. In India UNICEF's estimate of 11 million street children and In Kolkata there are 1 million children in the streets(UNICEF 2010).

Immediate and underlying factors of child migration to the street are actually non-income forms of poverty - Ill -Environment : Family breakdown, marriage breakdown, divorce, step parenting, domestic violence, beating, rebuked;

- Lack of community support, lack of extended family support, breakdown of support networks;

- Lack of parental education about child care and development.

- Conflict in family and stress management skills by the parents ;

- Assorted family problems including abuse;

non-income forms of poverty as:

- Desire for consumer good, the lure of the city;

- Unjust community structures and practices

- forced young marriage,

- Marginalization and exclusion (e.g. traditional gender roles that restrict education for women);

- Breakdown in traditional value system;

- Violation of Child right; 


\section{The Difficulties \& Problems Suffer by Street Children due to Migration:}

Street children live in an environment devoid of the affection, love, care and comfort of a family life. They are impelled by circumstances to struggle to fulfill their most basic needs like food and shelter at a very tender, impressionable age. Street children have a greater burden than other poor children who are supervised by adults. A description of the main problems that street children have to face under three main categories (not exclusive) i.e.

- Socio-educational,

- Physical, and

- Psychological, are:

\section{Socio-educational problems}

- Poverty and illiteracy: There is a lack basic resources to sustain a healthy living. They usually have no financial means to buy suitable clothings (which may be necessary in cold places), and no money to buy food, which is essential for their development. Because of the costs of services most street children cannot afford to go to school. Even where schools are free, many children cannot afford to buy uniforms, shoes and books.

- Wastage \& Stagnation: Wastage \& stagnation rate are remaining increase in Kolkata. As well as drop-out rate are high. Sarva shisha abhijan(SSA) \& minimum level of learning (MLL) program are not given satisfactory result in Kolkata.

- Violent Environment: The street is an unprotected environment where street children are exploited frequently. In some places, street children may even face the possibility of physical injuries or death from violence. Common sources of violence are: the police, gangs, drug syndicates, those who operate commercial sex businesses, death squads, other street children, families and sexual partners.

- Prostitution: Street children may prostitute themselves in order to survive - often to meet their addictions. A great deal of the exploitation remains clandestine. It occurs through contacts in nightclubs or bars or through high-end escort services where the abuse takes place in privately rented apartments.

- Trafficking: Trafficking consists of all acts of recruitment or transportation of persons within or across borders, involving deception, coercion or force, debt bondage or fraud, for the purpose of placing persons in situations of abuse or exploitation, such as forced prostitution, slavery, battering or extreme cruelty, sweatshop labor or exploitative domestic service.

\section{Physical problems}

- Lack of adequate nutrition: Even though some street children can usually get enough to eat, they do not have nutritious diets. This leads to malnutrition, anaemia and vitamin deficiencies.

- Injuries: Injuries may be caused intentionally (including injuring self while intoxicated or when depressed) and unintentionally

- Sexual and reproductive health problems: Common sexual and reproductive health problems include sexually transmitted diseases, HIV/AIDS, unwanted pregnancies and unsafe abortions. Sexual and reproductive health problems affect both girls and boys.

- Expose to diseases: Constant physical and mental strain and living in environment least protected against health hazards makes street children highly prone to infectious diseases.

\section{Psychological/mental problems}

- Aggression: The act of aggression is a kind of need satisfying behavior, by showing it child feel better because it paints up the feelings of frustration.

- Insecurity and Anxiety: Street children develop a number of psychological problems due to insecurity and continued anxiety, violation,maladjustive behavior throughout their lives. After being migrated to the street, children have to face police, the employer, the local criminals, and exploitation all as their own

Beside these many other problems are also faced by street children in their daily life --

Abuse, Child Labor, Gender Discrimination, Homelessness, Poverty, Loss of individual skills, identity, social \& moral values,self-estime.

\section{Life on the street of Kolkata:}

The glitter of Kolkata's urban life has been attracting the poor rural families, but they find themselves totally disappointed because the city of Kolkata has failed to fulfill their aspirations. However, there is no way to return for those poor people. All these have been adding to the population of the bustees (slums) and the jupries(shanties), many of whom are ultimately forced to seek shelter on the streets, under the over bridge, empty pipe on the road of Kolkata with their families. When a family cannot hold together, the children, who 
are half-fed and half-naked, must necessarily ramble about somewhere. These boys and girls who live and work on the street are vulnerable to wide and extreme violations of their rights. In the city of Kolkata, the huge number of marginalized children from these family, who are robbed of their childhood, are compelled to negotiate their precarious existence in the world of crime, misery, abuse and exploitation. They have difficulties in accessing basic services and are verbally, physically and sexually abused. Fast urbanization, high unemployment and aggravated poverty resulted in the increase of the numbers of children on the street. More than 100,000 minors, aged 5 to 18 , are street children. Few trust adults. Although these children may have a range of skills related to survival and informal income generation, their strength remains unarticulated and unrecognized by main stream society. Due to difficulty to earn money legally, they are forced into crime and confrontation with general public many times. Most of them seek temporary relief from this situation through substance abuse. They are trapped in cycle of poverty-violence-abuse. Forced to accept social exclusion from the beginning. Finally these children run the risk of increasing HIV/AIDS. .

\section{Objectives Of The Study:}

- To understand the educational status of street children in Kolkata,

- To explore the different types of problems presently faced by them,

- To find out the rehabilitation status among street children in Kolkata.

\section{Review of Literature}

The study of Street children is conducted in the light of other literature. Many previous investigations can be related to the present work. An attempt has been made to discuss only those studies or research work which are closely related to it.

1. Khalafalla Ahmed Mohamed Arabi, Wisal Altahir Ali, (2011) studied the factors that affect homelessness in Khartoum State on 300 street children. It is found that most of the street children were born in this State but the origins of the majority of them are the western and southern Sudan. Factor analysis was used and showed that there are seven factors which could be labeled city life, risky behavior, economic reasons, natural and environmental, family disruption, observation, and family abuse. The study recommended to locate perspective programs in areas where most street children families live in at present; intervening at home to prevent children from coming to streets; reduce school fees; create opportunities to increase income of vulnerable families specially those affected by war and drought; build trust with street children to convince them return home; provide safe night shelters for street children to protect them; help addicted children to overcome their addiction; reform and improve legislations and laws to protect children.

2. Soniya Wazed (2010) on her study explore the process of street migration with the interaction of both 'push' and 'pull' factors not only based on their economic necessities but also their livelihood strategies in street life. This research was exploratory in nature, conducted on Dhaka, Bangladesh. Study involved both street boys and girls respondents of different age groups selected purposively who are interviewed by semi structured interview schedule and field observation method are also used in this study. In this study the findings shows that street children were being 'pushed' and 'pulled' by various factors such as household poverty, family conflict, demands of the city life and violation of child rights etc. in which 'push' factors which was associated with the emotional bond between children and parents or guardians. break the adult-child relationship.. The rural-urban migration was also one of the important reasons for children to move on the street life which include natural disaster along with other causes.

3.Eme T. Owoaje, A.O. Adebiyi and M.C. Asuzu in (2009) stated that the concept of the street child in rural communities has received little attention. This study describes the socio demographic characteristics of 360 street children found in a group of rural communities. This descriptive study is nested in a cross sectional analytical study of street children in a group of rural communities undergoing urbanization. This study concluded the street child in rural communities differs from the urban perception which often has to do with those living rough and existing outside the family framework. More studies would be needed on the driving factors for street life in rural communities undergoing urbanization.

3. Pehlivanl1, Ezgi (2008), on his study assumes that street children can be explained in the context of social exclusion. On 15 street children he was employing qualitative methods, main aim of this study is to understand the reasons for children to start working on street, focuses on the findings from the life histories of children who work/live on streets of Ankara, in which two types of information, are analyzed in the context of Social Exclusion. 
4. Dharam Singh, Nishtha Sareen, Abhishek Ojha and Devendra Sareen (2008) find out the socio-cultural background, ecological factors and various problems faced by street children. This cross sectional study conducted in and around Udaipur city included 200 street children chosen randomly. After obtaining a detailed history regarding their caste, profession of their parents, family and environmental history, a detailed assessment of child labour was done. Special emphasis was laid upon child abuse, factors responsible for compelling them to adopt child labour and life style of these children. They concluded that the street children were subjected more frequently to child abuse. They were exposed to occupational hazards, deficiency diseases and had ambition to become a good citizen of the country. So, these street children must be provided tender care and emotional support and we must empower their educational and co-curricular activities, so that they attain a secure future.

6. Alessandro Conticini, David Hulme (2007) analysis of detailed empirical research in Bangladesh on 93 children in street situation. The main methods used were participant observation, play activities, in-depth interviews and group discussions. Towards the end of field research, a semi-structured questionnaire was utilized to triangulate the qualitative data that had been collected and to add a quantitative dimension to the analysis. It finds that social factors lie behind most street migration and, in particular, that moves to the street are closely associated with violence towards and abuse of children within the household and local community. In Bangladesh, those who seek to reduce the flow of children to the streets need to focus on social policy, especially on how to reduce the excessive control and emotional, physical and sexual violence that occur in some households. Economic growth and reductions in income poverty will be helpful, but they will not be sufficient to reduce street migration by children.

7.Farida habib, ramla nayaib, salma, kehkashan khan asra jamal, anila aman cheema and nausheen imam(2007) had conducted descriptive cross-sectional study on 50 street children (below 18 years of age and of both sexes) who were conveniently being selected to find out the physical, mental and social health problems of street children of Karachi. A questionnaire was designed consisting of 20 different close ended questions covering all the three parameters of health i.e., physical, mental and social regarding street children. Variables for physical health hazards were the effect of extremes of temperature, noise pollution, air pollution and lack of proper diet. Variables for mental health hazards were compulsion for work, kidnapping and lack of rest. Social health hazards were indulgence in substance use and sexual abuse. Street children were facing physical, mental and social health hazards.

8. Schimmel in Canada (2006), studied children who are in search of realization of basic needs move to the street. Running away from home might be an act of resistance and an expression of frustration with life circumstances. It is the strongest possible response to poverty and abuse that children in circumstances of deprivation and vulnerability can exercise. Their home life and street-life are both defined by two major forms of deprivation of basic needs and that are essential for healthy child development and socialization: a sound family life defined by supportive parents and intimate relationships and adequate social provisions of food, shelter, clothing, and quality schooling.

9.Joshi, Harish, Visaria, Leela and Bhat, Rajesh (2006) studied on153 street children at the main Kalupur Railway Station and under the nearby Sarangpur bridge. Children were interviewed to find out the reasons for leaving home, place of stay, duration of stay, occupations followed, earning and expenditure, harassment, treatment of sickness, willingness to study and feelings about being away from homes and family members. For the in depth study 34 street children were interviewed. Out of 153 street children, three were girls $(2 \%)$ and were interviewed at the Observation Home for Girls situated in Odhav where they were kept. To survive street children undertook a variety of occupations - bottle picking, cleaning train compartments and begging, working at tea/ snack stalls, rag picking, etc. Among the reasons for leaving home were harassment by family members, being orphans, for earning, did not want to study, family disintegration etc.

10. Duyan, (2005) on his study examines the relationships between socio-demographic and family characteristics, family relations, street life experiences and the hopelessness of street children. The study focuses on a population of street children living in the city of Gaziantep, Turkey, chosen for its high density of street children. Data were collected by distributing the Hopelessness Scale for Children and a questionnaire. In his research Duyan, interviewed 195 street children found significant relations between physical violence, father's alcohol usage, unemployment, threatening of the child at home, and hopelessness among street children and behaviors under this feeling's.

11. Tchombe, Therese M,(2002) reported that the opinions of street children, their parents and officials in social institution as to the causes of why the children move in to the street. The sample consists of 395 persons with social institutions from Bamenda in the North West Province of Cameron and also obtained relevant information 
from official documents literature on street children, questionnaire and focus group discussion. Analyzing the data through descriptive statistics, identified three main categories of causes: Social, Educational and Governmental. It was concluded that any programmatic interventions to prevent an increase of children drafting to the street should address the above issues and that of social policies which should make available amenities, activities, create opportunities to improve family life and provide vocational skills.

12. Association for Development, Delhi (2002) conducted a study among street and working children at old Delhi, New Delhi and Hazrat Nizamuddin railway stations to identify the reasons for leaving their homes and the problems faced by them in their day-to-day life. A sample of 100 respondents was taken and most of them were in the age group of 8-16years. Data was collected through questionnaire and it was found that children belonged to Uttar Pradesh and Bihar, had stayed in a home/government institution at one time or the other but some were wanted to remain on the streets, because of freedom and employment opportunities. In this study, Children mentioned abuse by parents as the main cause for having left their homes, they did not have any contact with their families, and did not want to go back to their families. Education should be an essential part of the programme to give them a better standard of life.

13. UNICEF (2002) conducted a study on sample of 260 street children in Zimbabwe. The objective of this study was to compile, consolidate and validate available information on street children in order to facilitate the development of a long-term national strategy aimed at promoting, protecting and fulfilling their rights. The major tools used in the study were interview schedules designed to investigate the situation of street children in Zimbabwe. This study cited the following as reasons for being on the streets; the need of earning income, being orphaned, abuse by step parents/relatives, inadequate care and support by parents or guardians and peer pressure.

After reviewing previous research works, process and causes of migration of street children to the capital it can be explained as the result of urban pull factors and rural push factors. This theory, specifically assumes that certain factors like job opportunities, land availability and social and cultural freedom in the area of destination operate as factors 'pulling' individual and children to urban areas. On the other hand, high population density, poor quality of education, the rupture of family relationship, natural calamities, lack of economic opportunities means poverty 'pushing' child migrants out of their rural origins. Studies showed, the hazardous life pattern of these children and in which they were involved in risk full jobs for survive.

\section{Hypotheses}

The Hypotheses were:

Hypothesis 1: There is significant difference in social status in terms of the living pattern of the children living with the family and without family

Hypothesis 2: There is significant difference in economic status in terms of the monthly income of the children belonging to nuclear and joint family.

Hypothesis 3: There is significant difference in economic status in terms of their monthly income of the children belonging to nuclear family and orphans.

Hypothesis 4: There is significant difference in economic status in terms of the monthly income of the children belonging to joint family and orphans.

Hypothesis 5: There is no significant difference in the motives of migration to the streets of Kolkata among the children coming from the areas outside Kolkata and West Bengal.

Hypothesis 6: There is no significant difference in the causal factors of migration among the children living with and without family.

Hypothesis No. 7: The variables are positively correlated, i.e. Street Children are positively correlated to Migration \& Poverty.

Hypothesis No. 8: The factor Street Children at Kolkata is directly attributed to migration.

Hypothesis No.9: There significant correlation between the socio-economic deprivation and education.

\section{Methodology}

a) Sample-The investigation was carried out on a sample of 600 street children ageing 2-16 years selected from streets of Kolkata. Simple random sampling method was employed to select the sample, due to this the Gender Distribution is not equally distributed.

The sample was randomly chosen by investigator and also NGOs who were helped in this study, on the basis of understanding and proper responding ability against the Structured Schedule. Data were collected from both North and South Kolkata. Interview, Observation and Schedule methods were applied for data collection.

b) Tools Used-The present study employed the following tool for data collection- 
Structured Schedule for Street children--- The problems of street children and rehabilitation status was assessed with the Structured Schedule for the Street Children.

Administration of the schedule :- In consultation with the selected NGOs and Child survey project officer of "NABADISHA", program of Kolkata Police , a tentative program schedule were fixed up for administration of Structured Schedule for Street children to the children who living on the street with or without family throughout Kolkata. Through interview of respondent or informant, investigator filled up the Schedule and collected the data. The responses given by the subject were carefully scrutinized on the spot by the investigator.

All items in the Structured Schedule for Street children were presented to a group of two experts to adjudge the suitability of the items in the present investigation.

- Interview, and

- Observation.

Variables under study:- i)Dependent variables- a)Migration

b)Poverty

ii)Independent Variables- Street Children

Statistical Analysis:-After data collection was completed scoring was found out . The extent of poverty and causal factor of migration was found out. Each of Hypothesis was statistically tested by using $\mathrm{T}$ test and results were found out.

\section{Findings and Analysis}

Table 1: Respondent Distribution According to Age Group and Family Association

\begin{tabular}{|l|l|l|l|l|}
\hline Age-Group & Children living with the family & Children living without the family & $\begin{array}{l}\text { Total } \\
\mathbf{n}=\mathbf{6 0 0}\end{array}$ & Percentage \\
\hline $\mathbf{2}-\mathbf{4}$ & 55 & 43 & 98 & 16.33 \\
\hline $\mathbf{5}-\mathbf{7}$ & 68 & 50 & 118 & 19.66 \\
\hline $\mathbf{8}-\mathbf{1 0}$ & 98 & 94 & 192 & 32 \\
\hline $\mathbf{1 1}-\mathbf{1 3}$ & 76 & 58 & 134 & 22.33 \\
\hline $\mathbf{1 4}-\mathbf{1 6}$ & 31 & 27 & 58 & 9.66 \\
\hline
\end{tabular}

Figure 1: Respondent distributuon according to the Age-Group and Family Association

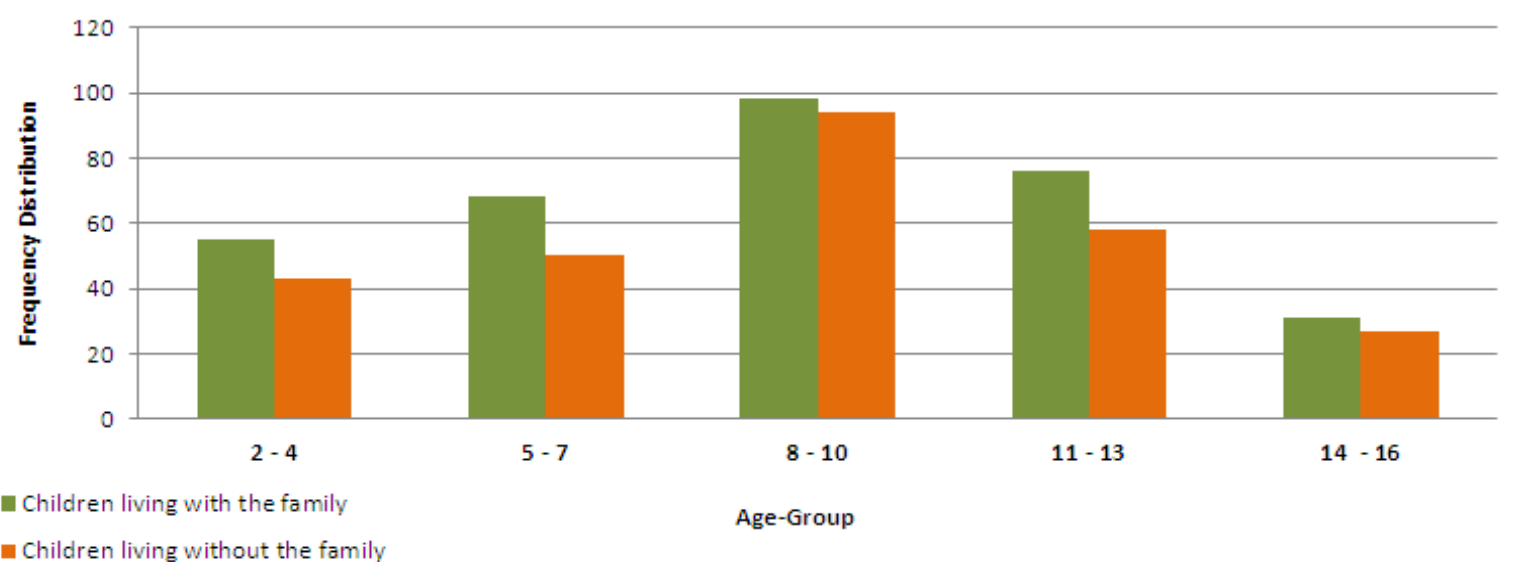

Statistical Description:

\begin{tabular}{|l|l|l|l|l|l|l|}
\hline $\begin{array}{l}\text { Grouped } \\
\text { Respondents }\end{array}$ & Mean & Median & $\begin{array}{l}\text { Standard } \\
\text { Deviation }\end{array}$ & $\begin{array}{l}\text { Sample } \\
\text { Variance }\end{array}$ & Kurtosis & Skewness \\
\hline $\begin{array}{l}\text { Children living with the } \\
\text { family }\end{array}$ & 65.6 & 68 & 24.86 & 618.3 & 0.36 & -0.2 \\
\hline $\begin{array}{l}\text { Children living without } \\
\text { the family }\end{array}$ & 54.4 & 50 & 24.9 & 620.3 & 1.87 & 1.07 \\
\hline
\end{tabular}

Table 2: Gender Distribution of Street Children

\begin{tabular}{|l|l|l|l|l|}
\hline Gender & Children living with the family & Children living without the family & Total $\mathbf{n = 6 0 0}$ & Percentage \\
\hline Male & 213 & 179 & 392 & 65.33 \\
\hline Female & 115 & 93 & 208 & 34.66 \\
\hline
\end{tabular}




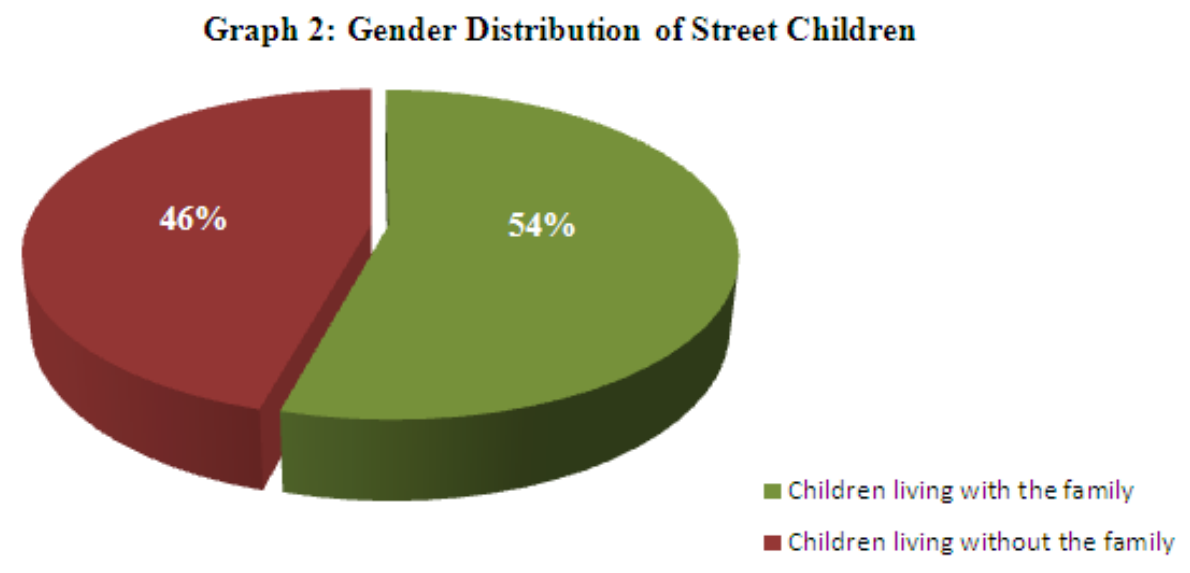

Statistical Description:

\begin{tabular}{|l|l|l|l|}
\hline $\begin{array}{l}\text { Grouped } \\
\text { Respondents }\end{array}$ & Mean & $\begin{array}{l}\text { Standard } \\
\text { Deviation }\end{array}$ & $\begin{array}{l}\text { Sample } \\
\text { Variance }\end{array}$ \\
\hline Male & 196 & 24.04 & 578 \\
\hline Female & 104 & 15.55 & 242 \\
\hline
\end{tabular}

Educational Back-ground of the Street Children According to the Family Association Hypothesis no : (9)Table 3.1: Literacy vs. Illiteracy among Street Children

\begin{tabular}{|l|l|l|l|l|}
\hline Education & Children living with the family & Children living without the family & Total $\mathbf{n}=\mathbf{6 0 0}$ & Percentage \\
\hline Literate & 250 & 180 & 430 & 71.66 \\
\hline Illiterate & 78 & 92 & 170 & 28.33 \\
\hline
\end{tabular}

Graph 3.1: Literacy vs. Illiteracy among Street Children

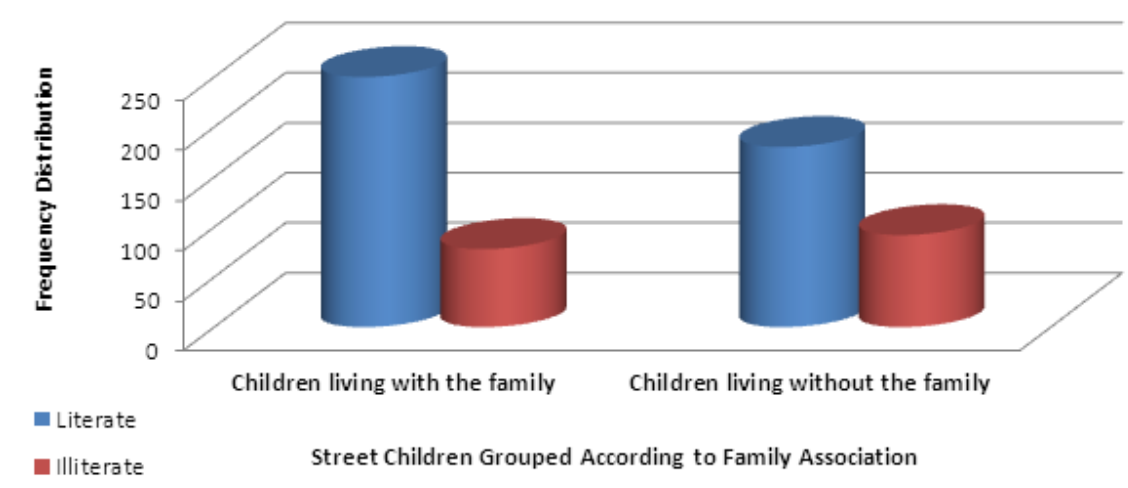

Statistical Description:

\begin{tabular}{|l|l|l|l|}
\hline $\begin{array}{l}\text { Grouped } \\
\text { Respondents }\end{array}$ & Mean & $\begin{array}{l}\text { Standard } \\
\text { Deviation }\end{array}$ & $\begin{array}{l}\text { Sample } \\
\text { Variance }\end{array}$ \\
\hline Literate & 215 & 49.49 & 2450 \\
\hline Illiterate & 85 & 9.89 & 98 \\
\hline
\end{tabular}

Table 3.2: Pattern of Literacy among Street Children

\begin{tabular}{|l|l|l|l|l|}
\hline Pattern of Literacy & $\begin{array}{l}\text { Children living with the } \\
\text { family }\end{array}$ & $\begin{array}{l}\text { Children living without } \\
\text { the family }\end{array}$ & Total n=430 & Percentage \\
\hline Continue School & 132 & 0 & 132 & 30.69 \\
\hline School Drop Out & 95 & 137 & 232 & 53.95 \\
\hline Open School Learning & 23 & 43 & 66 & 15.34 \\
\hline
\end{tabular}




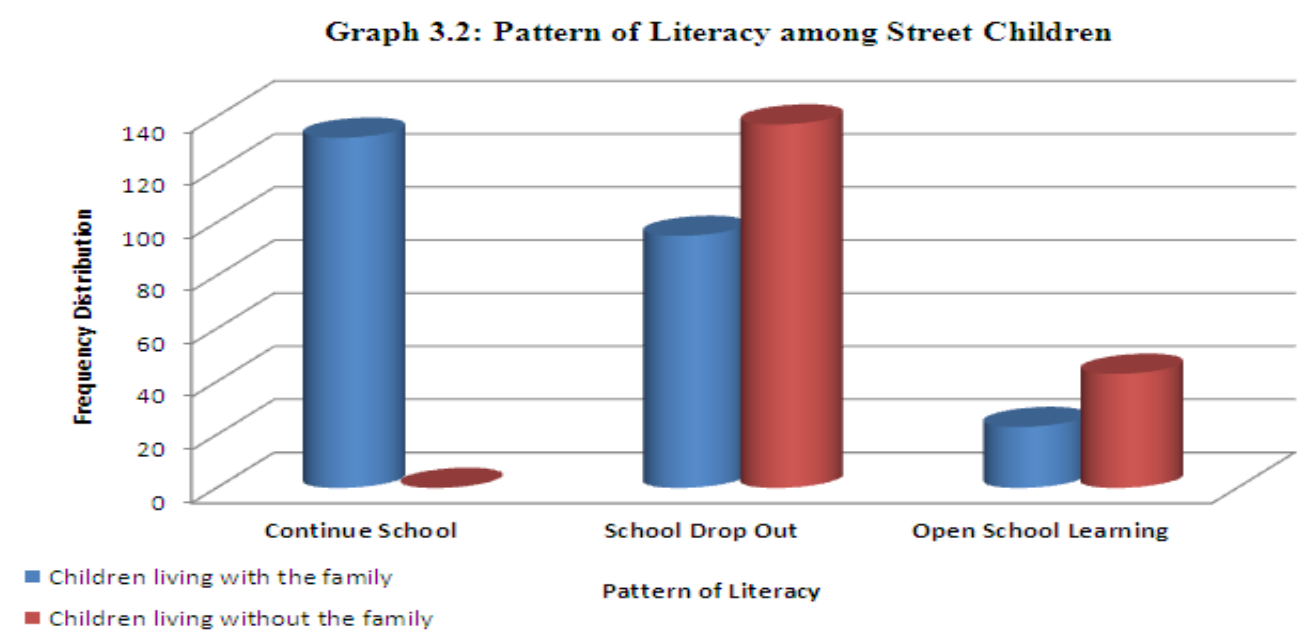

\section{Statistical Description:}

\begin{tabular}{|l|l|l|l|}
\hline $\begin{array}{l}\text { Grouped } \\
\text { Respondents }\end{array}$ & Mean & $\begin{array}{l}\text { Standard } \\
\text { Deviation }\end{array}$ & $\begin{array}{l}\text { Sample } \\
\text { Variance }\end{array}$ \\
\hline Continue School & 66 & 93.33 & 8712 \\
\hline School Drop Out & 116 & 29.69 & 882 \\
\hline Open School Learning & 33 & 14.14 & 200 \\
\hline
\end{tabular}

Table 7.6: Expected Resolution of Migration among Street Children

\begin{tabular}{|l|l|l|l|}
\hline Expected Resolution of Migration & Access & Not able to access & Not aware of \\
\hline AwasYojna of Government & 2 & 85 & 462 \\
\hline Assistance of House Making & 0 & 87 & 462 \\
\hline $\begin{array}{l}\text { Use of tube well / Well \& Drinking } \\
\text { Water }\end{array}$ & 425 & 5 & 100 \\
\hline Ration System for BPL & 6 & 133 & 421 \\
\hline Free Education & 155 & 70 & 7 \\
\hline $\begin{array}{l}\text { Employment Opportunity at their } \\
\text { native place }\end{array}$ & 15 & 18 & 99 \\
\hline Self Help Program at native place & 3 & 4 & 125 \\
\hline
\end{tabular}

Graph 7.5: Expected Resolution of Migration among Street Children

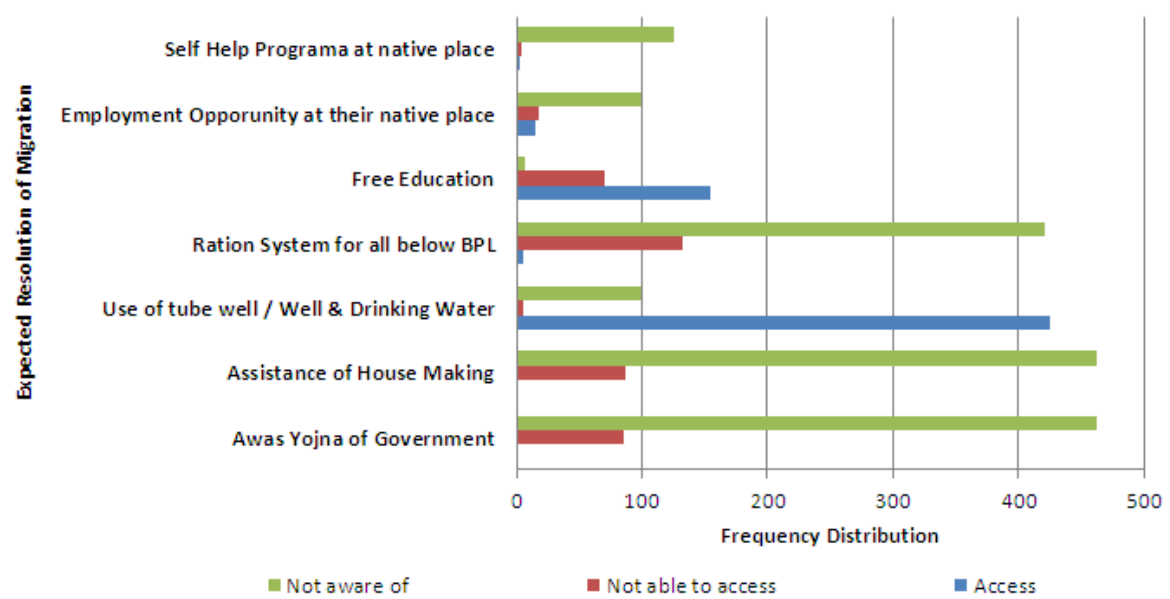

Data shows that, among 600 children 462 are not aware about the Awash yojona of Govt. only 2 children can access it and 85 children know about it but they cant access it due to many rules and regulation.In the category of access of services provided by govt. (corporation), maximum street children (425) can use tube well for drinking water. On the other hand, in the case Ration System for BPL, 133 children are not able to 
access it and 421 children do not know about this. Same picture are seen in the assistance of house making where 462 children are not aware about it

Table 7.6.5: Pattern of Education of Children before Migration

\begin{tabular}{|l|l|l|l|}
\hline Pattern of Education & School & Pathsala & Tuition \\
\hline Number of Children & 383 & 45 & 02 \\
\hline
\end{tabular}

Table 7.6.5: Pattern of School of Children After Migration

\begin{tabular}{|l|l|l|l|}
\hline Pattern of School & Regular & Open & Dropout \\
\hline Number of Children & 132 & 66 & 232 \\
\hline
\end{tabular}

Pattern of Education of Children before Migration
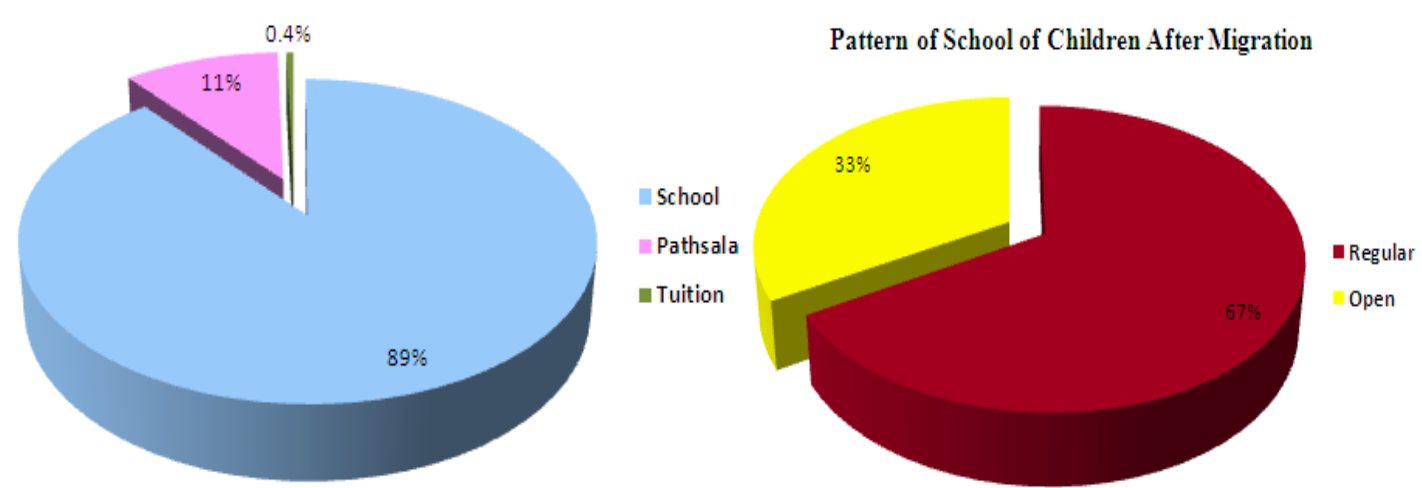

Table 3.4: Level of Education among Street Children

\begin{tabular}{|l|l|l|l|l|}
\hline Levels of Literacy & $\begin{array}{l}\text { Children living with } \\
\text { the family }\end{array}$ & $\begin{array}{l}\text { Children living without } \\
\text { the family }\end{array}$ & Total n=430 & Percentage \\
\hline $\begin{array}{l}\text { Only signature/Nursery } \\
\text { KG I / II }\end{array}$ & $45(10.46 \%)$ & $60(13.95 \%)$ & 105 & 24.41 \\
\hline Class I - V & $109(18.16 \%)$ & $83(19.30 \%)$ & 192 & 44.65 \\
\hline Class VI - IX & $96(22.32 \%)$ & $37(8.60 \%)$ & 133 & 30.93 \\
\hline \multicolumn{1}{|c|}{ Total } & $\mathbf{2 5 0}(\mathbf{5 8 . 1 3 \% )}$ & $\mathbf{1 8 0}(\mathbf{4 1 . 4 6 \% )})$ & $\mathbf{4 3 0}$ & $\mathbf{1 0 0}$ \\
\hline
\end{tabular}

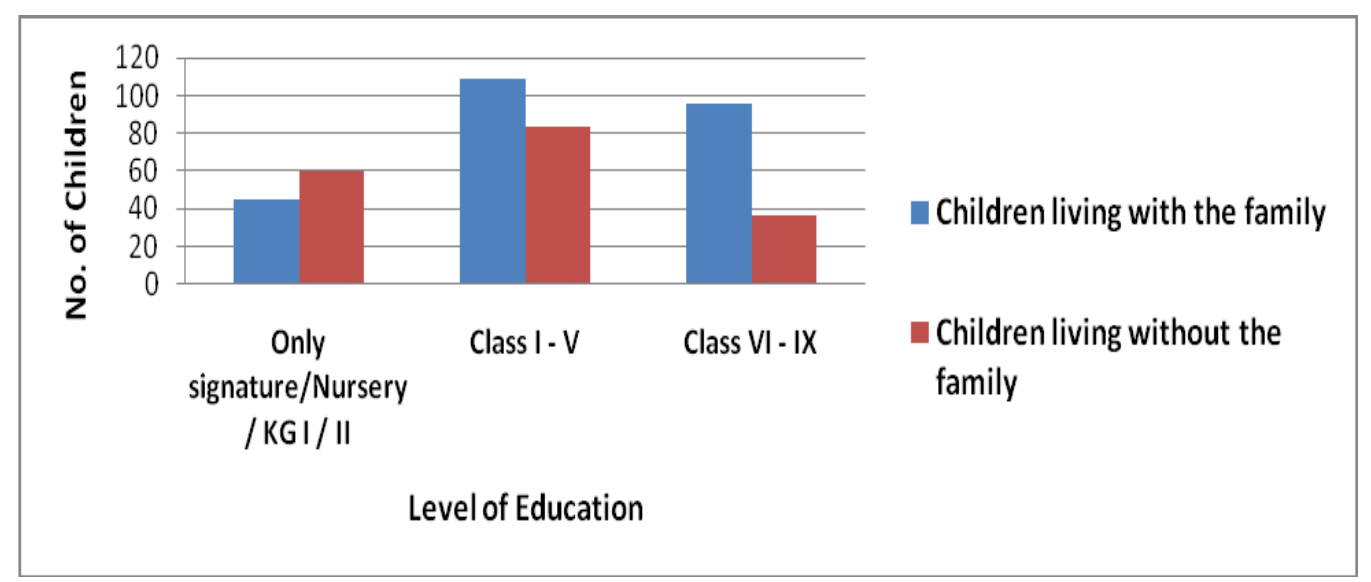

Graph3.1: Level of Education among Street Children

Level of education among the street children ranged from preprimary to class IX. None has passed the Madhyamik exam because the dropout rate is very high in primary education level i.e. class 1 to 4.

$24.41 \%$ (105) children's educational level is preprimary i.e. nursery or Kg-1 or K.g-2. $44.65 \%$ (192) children's educational level primary i.e. class $1-4$ and 30.93\% (133) children's educational level is class -VI- IX. The children who are living with family, their educational level is primary and class VI- IX are better than who are not living with family. 
Housing and Household Acquaintance of Street Children

Table 4.1: Living in Place of Street Children After Migration

\begin{tabular}{|l|l|l|}
\hline Living Place & Number of Children & Percentage \\
\hline Street & 242 & $40 \%$ \\
\hline Station & 125 & $21 \%$ \\
\hline Bus Stand & 96 & $16 \%$ \\
\hline Pavement & 137 & $23 \%$ \\
\hline Total & 600 & $100 \%$ \\
\hline
\end{tabular}

Graph 4.1: Living in Place of Children after Migration

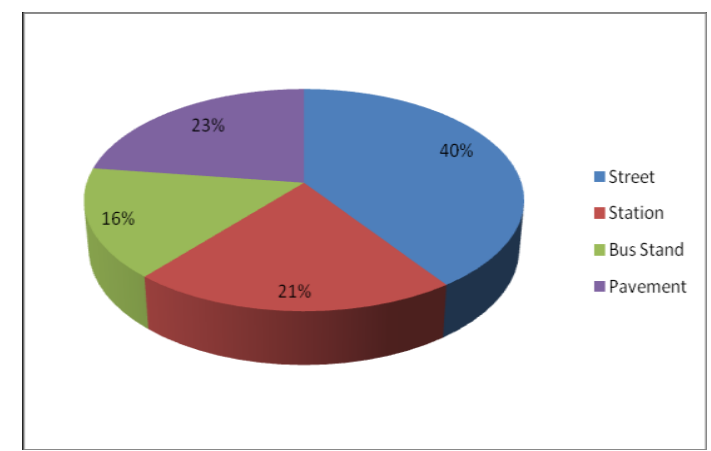

Among 600 children,40\% (242)are living on the street,23\%(137) are bus stand and 21\%(125) are living on a station after migration in the streets of Kolkata from their native place. Rest of the children are taken shelter in bus stand.

Table 4.2: Housing Pattern of Street Children

\begin{tabular}{|l|l|l|l|l|}
\hline Pattern of House & $\begin{array}{l}\text { Children living with the } \\
\text { family }\end{array}$ & $\begin{array}{l}\text { Children living without } \\
\text { the family }\end{array}$ & $\begin{array}{l}\text { Total } \\
\text { n=600 }\end{array}$ & Percentage \\
\hline Permanent house & $14(2.33 \%)$ & $2(0.33 \%)$ & 16 & $2.66 \%$ \\
\hline Temporary house & $243(40.5 \%)$ & $186(31 \%)$ & 429 & $71.5 \%$ \\
\hline $\begin{array}{l}\text { Temporary house on } \\
\text { street }\end{array}$ & $53(8.83 \%)$ & $12(2 \%)$ & 65 & $10.83 \%$ \\
\hline Homeless & $18(3 \%)$ & $72(12 \%)$ & 90 & $15 \%$ \\
\hline Total & $\mathbf{3 2 8 ( 5 4 . 6 6 \% )}$ & $\mathbf{2 7 2}(\mathbf{4 5 . 3 3 \% )}$ & $\mathbf{6 0 0}$ & \\
\hline
\end{tabular}

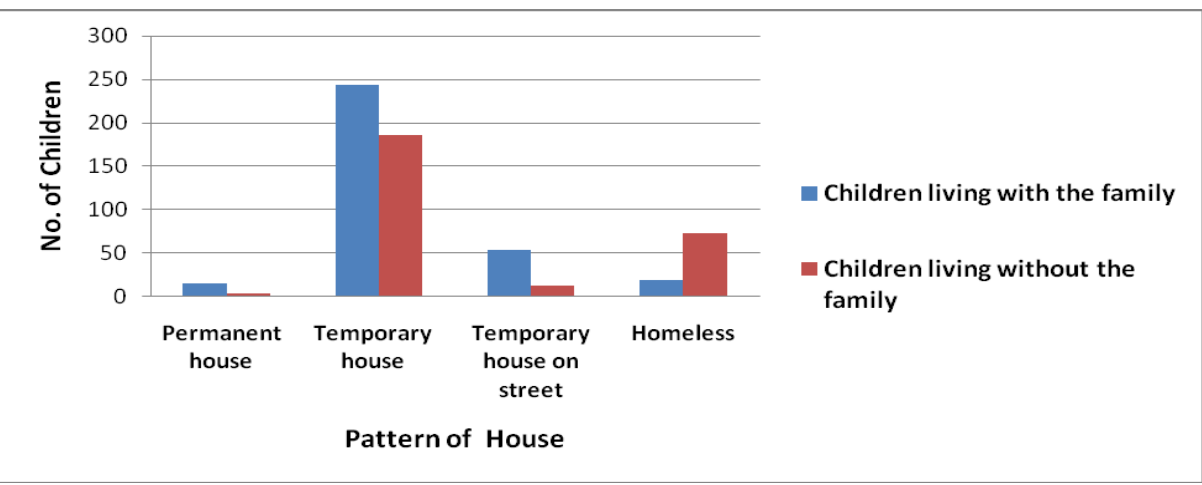

\section{Graph 4.2: Housing Pattern of Street Children}

Among the all children of the study,2.66\%(16) are lived in permanent house on street which is made with bamboo, tally and plastic.71.5\%(429) children living in temporary house which is made with only plastic. Beside these, rest of them living on road side/pavement and $15 \%(90)$ are completely homeless.

Table 4.3: Type of House of Children after Migration

\begin{tabular}{|l|l|}
\hline Type of House of Children after Migration & Number of Children \\
\hline Homeless & $90(15 \%)$ \\
\hline Mud & $16(3 \%)$ \\
\hline Poly thin & $429(71 \%)$ \\
\hline Tripoli & $65(11 \%)$ \\
\hline
\end{tabular}




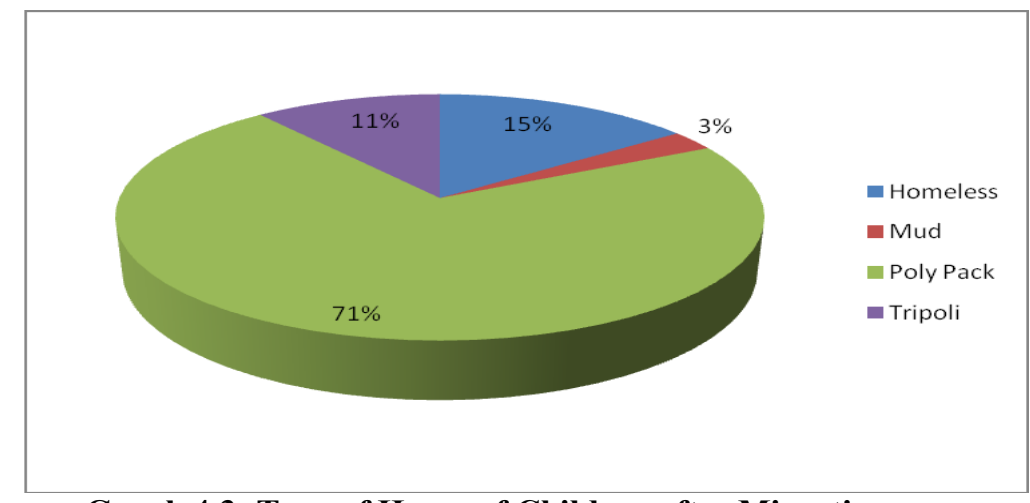

Graph 4.3: Type of House of Children after Migration

Above data shown that, children who are living in temporary houses, are made with mud(3\%), polythin (71\%) and Tripoli $(11 \%)$, where as $15 \%$ are completely homeless.

Table 4.4: House Hold Acquaintance of Street Children

\begin{tabular}{|c|c|c|c|c|}
\hline $\begin{array}{ll}\text { Housing } & \text { Hold } \\
\text { Acquaintance } & \\
\end{array}$ & $\begin{array}{l}\begin{array}{l}\text { Children living with } \\
\text { the family } \mathrm{n}=328\end{array} \\
\end{array}$ & $\begin{array}{l}\text { Children living without } \\
\text { the family } n=272\end{array}$ & $\begin{array}{l}\text { Total } \\
\mathbf{n}=600\end{array}$ & Percentage \\
\hline Furniture & $310(51.66 \%)$ & $188(31.33 \%)$ & 498 & $83 \%$ \\
\hline Utensils & $310(51.66 \%)$ & $188(31.33 \%)$ & 498 & $83 \%$ \\
\hline Electric Appliances & $284(47.33 \%)$ & $234(39 \%)$ & 518 & $86.33 \%$ \\
\hline Gas Oven & $83(13.83 \%)$ & $9(1.5 \%)$ & 92 & $15.33 \%$ \\
\hline Chula & $227(37.83 \%)$ & 0 & 227 & $37.83 \%$ \\
\hline Cycle & $17(2.83 \%)$ & $8(1.33 \%)$ & 25 & $4.16 \%$ \\
\hline Proper Toys to play & $107(17.83 \%)$ & 0 & 107 & $17.83 \%$ \\
\hline
\end{tabular}

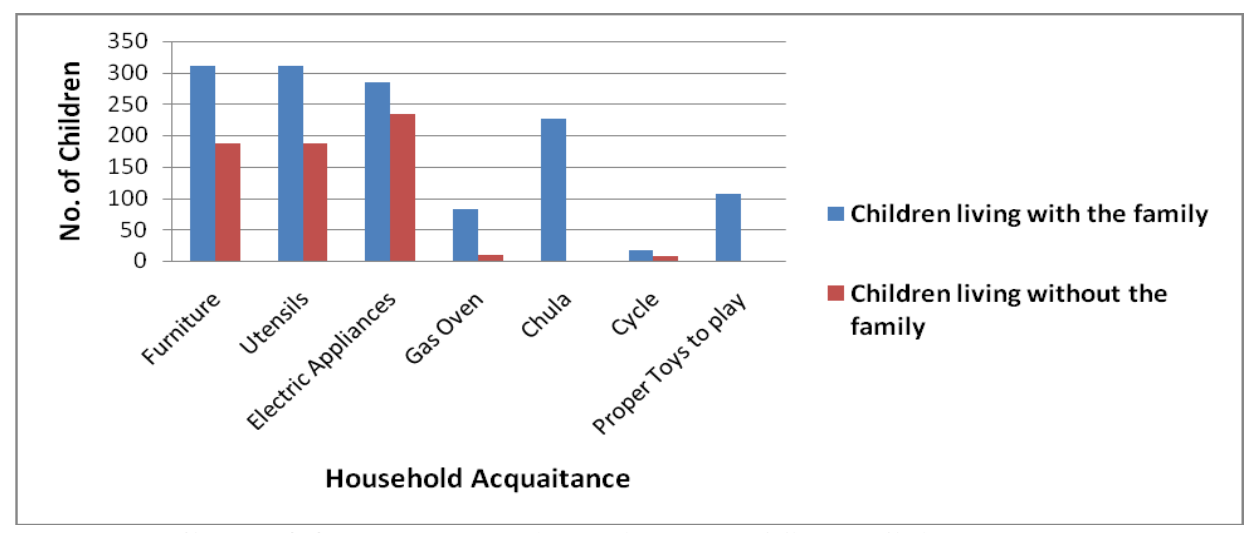

Graph 4.4: House Hold Acquaintance of Street Children

Among the street children, who are living with the family have more house hold acquaintance than children living without the family.

Furniture-old chowki, khatia, trunk, broken dressing table, broken mirror and the utensils-thali, bowl, glasses, spoon i.e. daily use materials have $83 \%(498)$ of both type of children who are living with or without family. $86.33 \%(518)$ children have electric appliances like, radio, mobile, T.V run by hooking electricity . $15.33 \%$ (92) children have gas oven.37.83\%(227) children have chulahs ,4.16\%(25) have cycles and $17.83 \%(107)$ have toys which are broken, oldnand dirty as per observation.

But children, who are living without family have no chulah or even broken toys, because they don't cook for themselves at all and nobody give them toys for recreation. 


\section{Occupational Status of the Street Children According to the Family Association}

Table 5:1: Occupational Status among Street Children

\begin{tabular}{|l|l|l|}
\hline $\begin{array}{l}\text { Occupational } \\
\text { Engagement }\end{array}$ & Yes & No \\
\hline $\begin{array}{l}\text { Number of Children } \\
\text { (before Migration) }\end{array}$ & $\mathbf{8 5 ( 1 4 . 1 6 \% )}$ & $\mathbf{5 1 5 ( 8 5 . 8 3 \% )}$ \\
\hline $\begin{array}{l}\text { Number of Children } \\
\text { (after Migration) }\end{array}$ & $468(78 \%)$ & $132(22 \%)$ \\
\hline
\end{tabular}

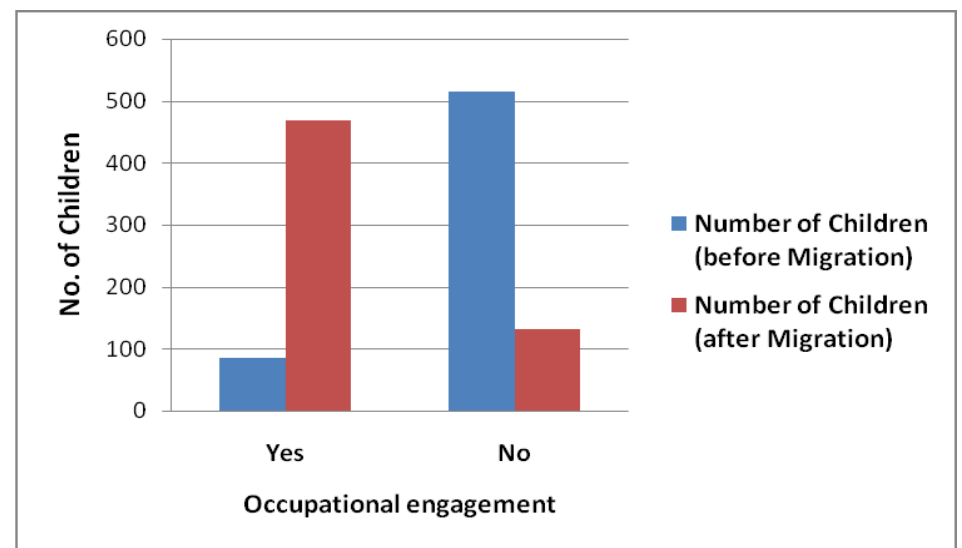

Figure 5.1: Occupational Status among Street Children

Above data shown, among 600 children, 85 children are engaged in job before migration in their native place. After the migration to the streets of Kolkata 468 children getting job for their livelihood.

Table 5.2: Child Labor among Street Children

\begin{tabular}{|l|l|l|l|l|}
\hline Child Labor & $\begin{array}{l}\text { Children living with } \\
\text { the family }\end{array}$ & $\begin{array}{l}\text { Children living without } \\
\text { the family }\end{array}$ & $\begin{array}{l}\text { Total } \\
\mathbf{n}=\mathbf{6 0 0}\end{array}$ & Percentage \\
\hline Worker & $196(32.66 \%)$ & $272(45.33 \%)$ & 468 & $78 \%$ \\
\hline Non- Worker & $132(22 \%)$ & 0 & 132 & $22 \%$ \\
\hline Total & $\mathbf{3 2 8}(\mathbf{5 4 . 6 6 \% )}$ & $\mathbf{2 7 2 ( 4 5 . 3 3 \% )}$ & $\mathbf{6 0 0}$ & \\
\hline
\end{tabular}

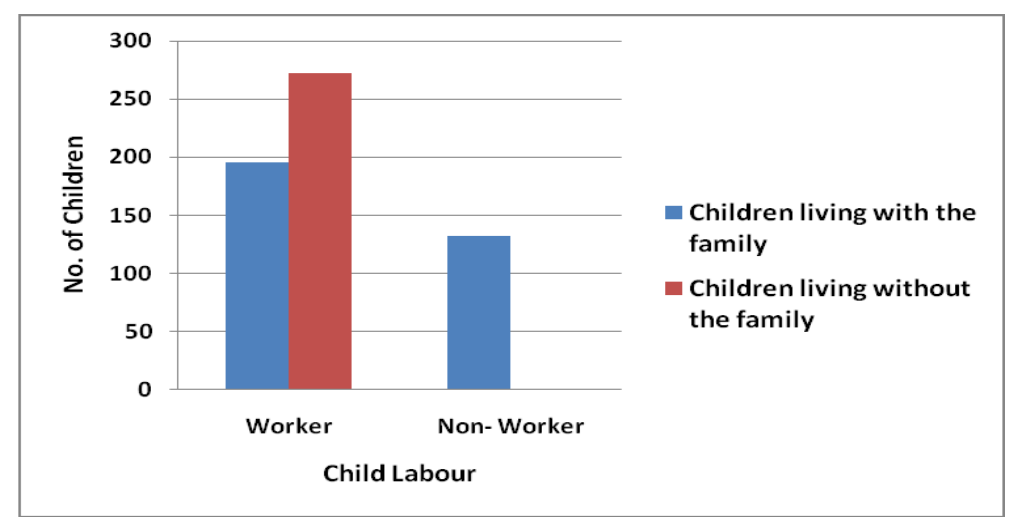

Graph 5.2: Child Labor among Street Children

Among the 600 children $78 \%$ (468) are workers and they earn money. The informants are also include as they are used as money earners.

Non worker children $22 \%$ (132) are not earning money by any means and are living with the family. The number of working children is higher among those who are not living with the family and lead their life with this earning. 
Table 5:3: Duration of Job Engagement Among Street Children

\begin{tabular}{|l|l|l|}
\hline $\begin{array}{l}\text { Duration of Job } \\
\text { Engagement }\end{array}$ & $\begin{array}{l}\text { Number of Children } \\
\text { (before Migration }\end{array}$ & $\begin{array}{l}\text { Number of Children } \\
\text { (after Migration) }\end{array}$ \\
\hline Short & $20(23.52 \%)$ & $132(28.20 \%)$ \\
\hline Long & $50(58.82 \%)$ & $336(71.79 \%)$ \\
\hline No Fixed Time & $15(17.64 \%)$ & -- \\
\hline Total & 85 & 468 \\
\hline
\end{tabular}

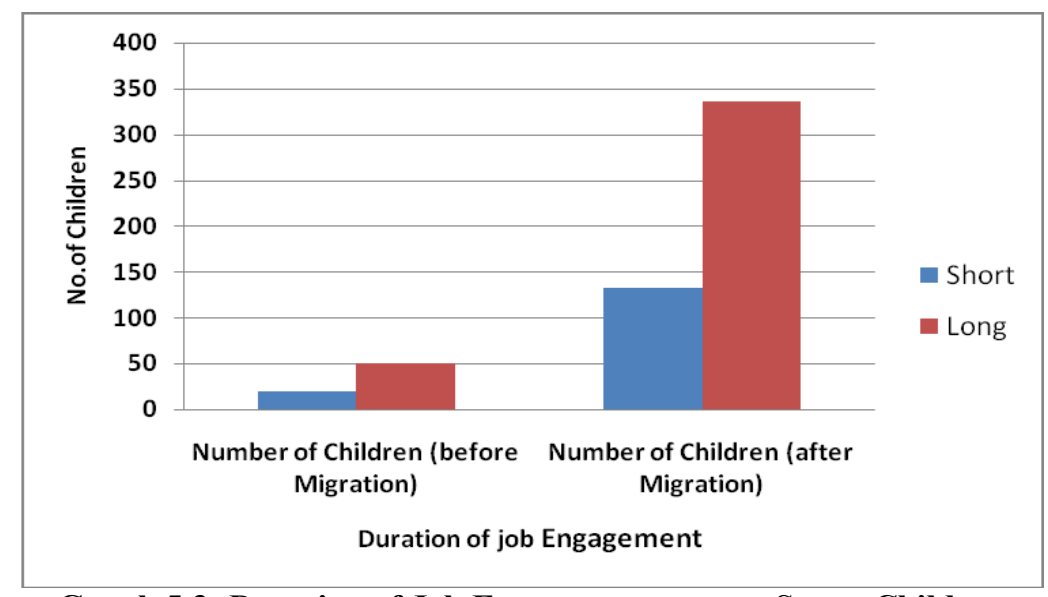

Graph 5.3: Duration of Job Engagement among Street Children

Among 600 children, duration of Job Engagement are much long after migration (511) than before migration (70).

In above table, job engagement of children before migration though 85 , but the calculation done on 70 respondents because rest of the 15 respondents are engage in subsidiary work which have no proper time duration.

\begin{tabular}{|c|c|c|c|}
\hline Pattern & Types & Children living with family & $\begin{array}{l}\text { Children living } \\
\text { without family }\end{array}$ \\
\hline \multirow{9}{*}{ Non-Hazardous } & 1)Begging & $53(11.32 \%)$ & $65(13.88 \%)$ \\
\hline & 2)Washing car/ shop windows & $20(4.27 \%)$ & $36(7.69 \%)$ \\
\hline & $\begin{array}{l}\text { 3) Selling item on the street } \\
\text { (including veg. and fruits) }\end{array}$ & $26(5.55 \%)$ & $42(8.97 \%)$ \\
\hline & 4) Shining shoes & $2(0.42 \%)$ & 0 \\
\hline & 5)Working in tea stall & $3(0.64 \%)$ & $7(1.49 \%)$ \\
\hline & 6) Working in piece hotel & $2(0.42 \%)$ & $10(2.13 \%)$ \\
\hline & 7) maid servant & $3(0.64 \%)$ & $5(1.06 \%)$ \\
\hline & 8) Van driver & $3(0.64 \%)$ & $3(0.64 \%)$ \\
\hline & $\begin{array}{l}\text { 9) Working in garage( Car } \\
\text { repaired) }\end{array}$ & $2(0.42 \%)$ & $3(0.64 \%)$ \\
\hline \multirow{7}{*}{ Hazardous } & $\begin{array}{l}\text { 10) Rag / used paper / metal } \\
\text { /picker }\end{array}$ & $41(8.76 \%)$ & $45(9.61 \%)$ \\
\hline & $\begin{array}{l}\text { 11) Factory Worker } \\
\text { (Agarbati/match boxes /bidi } \\
\text { industries/ fire works etc.) }\end{array}$ & $13(2.77 \%)$ & $19(4.05 \%)$ \\
\hline & $\begin{array}{l}\text { 12)Helper (construction), } \\
\text { labor }\end{array}$ & $3(0.64 \%)$ & $11(2.35 \%)$ \\
\hline & 13) Cinema Ticket blacking & $7(1.49 \%)$ & $10(2.13 \%)$ \\
\hline & 14 Prostitution & $1(0.21 \%)$ & $4(0.85 \%)$ \\
\hline & 15) Substance padding & $15(3.20 \%)$ & $7(1.49 \%)$ \\
\hline & 16) No fixed jobs & $2(0.42 \%)$ & $8(1.70 \%)$ \\
\hline
\end{tabular}

Table 5.4: Pattern and Type of Labor among Street Children

Data revealed that, street children are engaged in various types of Hazardous work like rag picker, helper etc. and Non-hazardous work like begging, house maid, car washing, selling item on the street etc. 


\section{5: Pattern of Labor among Street Children}

\begin{tabular}{|l|l|l|l|l|}
\hline Pattern of Labor & $\begin{array}{l}\text { Children living with } \\
\text { the family }\end{array}$ & $\begin{array}{l}\text { Children living without the } \\
\text { family }\end{array}$ & $\begin{array}{l}\text { Total } \\
\text { n=468 }\end{array}$ & Percentage \\
\hline Hazardous & $80(17.09 \%)$ & $96(20.51 \%)$ & 176 & $37.6 \%$ \\
\hline Non - Hazardous & $116(24.78 \%)$ & $176(37.60 \%)$ & 292 & $62.39 \%$ \\
\hline Total & $196(41.88 \%)$ & $272(58.11 \%)$ & 468 & $100 \%$ \\
\hline
\end{tabular}

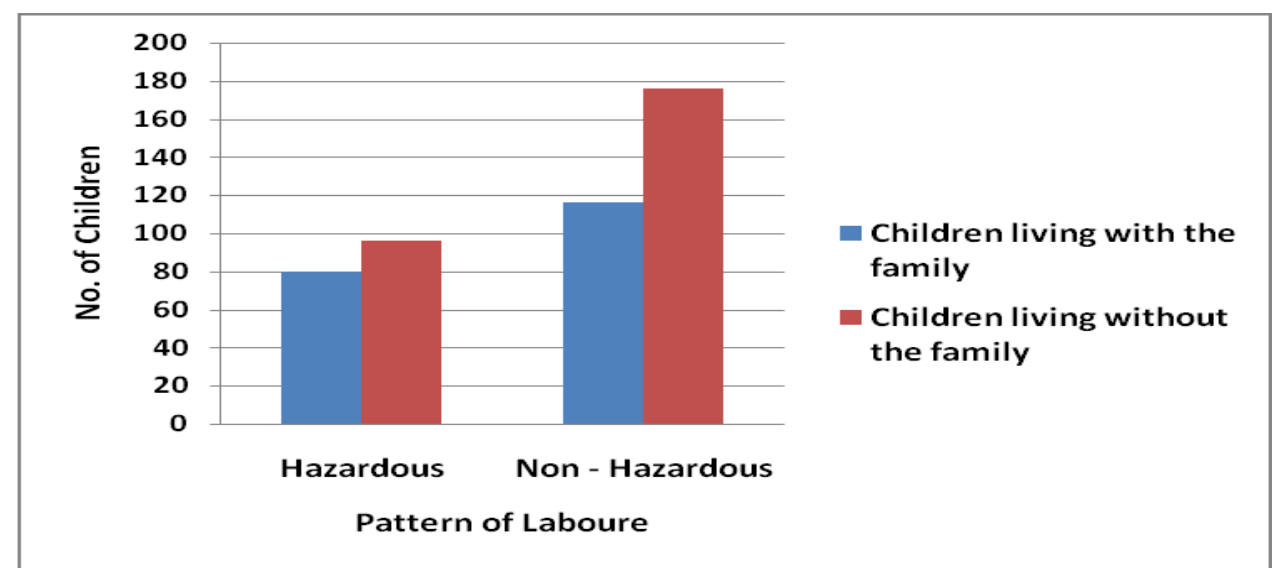

Graph 5.5: Pattern of Labor among Street Children Statistical Description:

\begin{tabular}{|l|l|l|l|}
\hline $\begin{array}{l}\text { Pattern of } \\
\text { Labor }\end{array}$ & Mean & $\begin{array}{l}\text { Standard } \\
\text { Deviation }\end{array}$ & $\begin{array}{l}\text { Sample } \\
\text { Variance }\end{array}$ \\
\hline Hazardous & 88 & 11.31 & 128 \\
\hline Non - Hazardous & 146 & 42.426 & 1800 \\
\hline
\end{tabular}

Among the working children, who earn money for themselves or their family are involved in both Hazardous and Non hazardous types of work.

The children working in a factory, involved with padding of addiction material like ganja, Charas or a sex worker, blacker, wagon breaker are under the hazardous labor pattern in which children who are living without the family are more involved than who are living with family.

In non hazardous category also children living without family are more than other category. Tea stall worker, hotel worker, cleaner in a restaurant, hawker, and housemaid are non hazardous category of work.

Table 5.6: Pattern of Occupation among Street Children

\begin{tabular}{|l|l|l|l|l|}
\hline $\begin{array}{l}\text { Pattern of } \\
\text { Occupation }\end{array}$ & $\begin{array}{l}\text { Children living with the } \\
\text { Family }\end{array}$ & $\begin{array}{l}\text { Children living without } \\
\text { the family }\end{array}$ & $\begin{array}{l}\text { Total } \\
\mathbf{n = 4 6 8}\end{array}$ & $\begin{array}{l}\text { Percentage } \\
(\%)\end{array}$ \\
\hline Primary & $173(36.96 \%)$ & $186(39.74 \%)$ & 359 & 76.7 \\
\hline Secondary & $23(4.91 \%)$ & $82(17.52 \%)$ & 105 & 22.43 \\
\hline Subsidiary & $43(9.18 \%)$ & $4(0.85 \%)$ & 47 & 10.04 \\
\hline
\end{tabular}

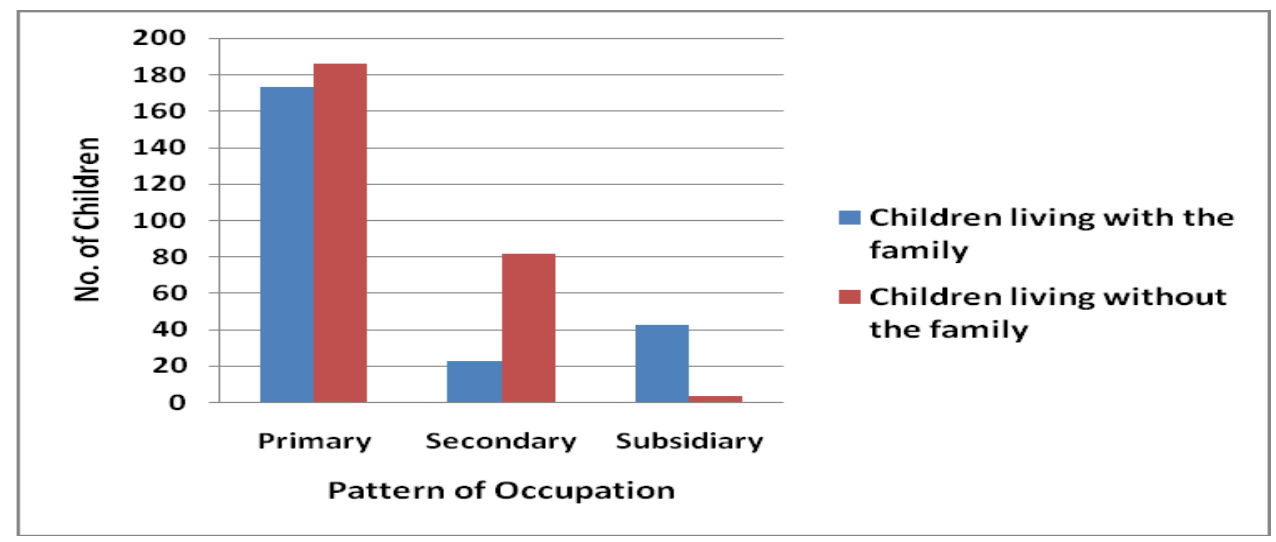

Graph 5.6: Pattern of Occupation among Street Children Statistical Description: 


\begin{tabular}{|l|l|l|l|}
\hline $\begin{array}{l}\text { Pattern of } \\
\text { Occupation }\end{array}$ & Mean & $\begin{array}{l}\text { Standard } \\
\text { Deviation }\end{array}$ & $\begin{array}{l}\text { Sample } \\
\text { Variance }\end{array}$ \\
\hline Primary & 179.5 & 9.19 & 84.5 \\
\hline Secondary & 52.5 & 41.71 & 1740.5 \\
\hline Subsidiary & 23.5 & 27.57 & 760.5 \\
\hline
\end{tabular}

Data shown that, among 468 working children,maximum children(359;76:7\%)are involved in primary occupation .such as begging, rag/metal/plastic picking, selling items on street, etc. which fall under both hazardous and non-hazardous category.In secondary pattern of occupation children are involved more than subsidiary pattern of occupation in which washing car/shop windows, etc. are included along with primary type of occupation..

Table 5.7: Pattern of Job Engagement Among Street Children

\begin{tabular}{|l|l|l|l|}
\hline $\begin{array}{l}\text { Pattern of Job } \\
\text { Engagement }\end{array}$ & Full Time & Part Time & Total \\
\hline $\begin{array}{l}\text { Number of Children } \\
\text { (before Migration) }\end{array}$ & $42(49.11 \%)$ & $43(50.58 \%)$ & 85 \\
\hline $\begin{array}{l}\text { Number of Children } \\
\text { (after Migration) }\end{array}$ & $132(28.20 \%)$ & $336(71.79 \%)$ & 468 \\
\hline
\end{tabular}

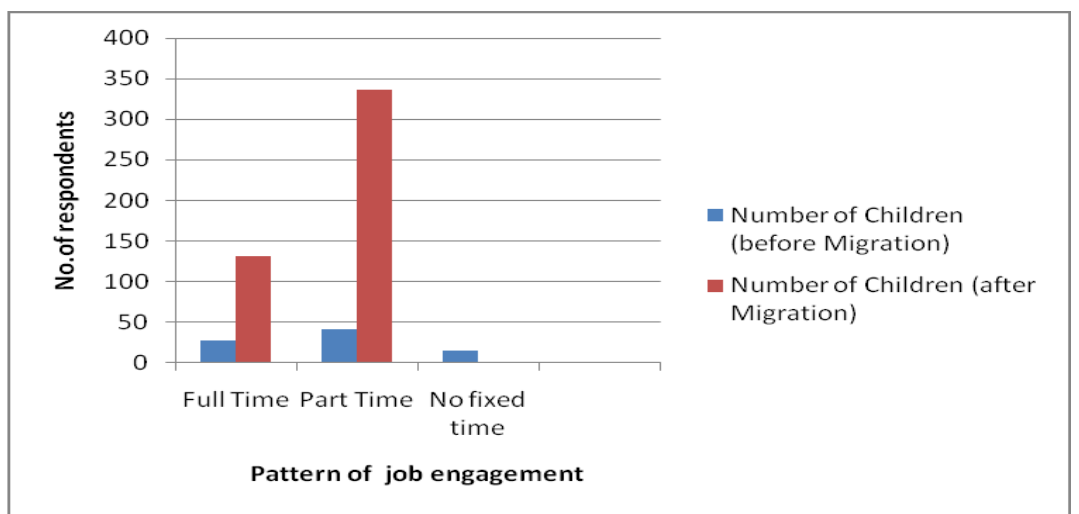

Graph 5.7: Pattern of Job Engagement among Street Children

The above data revealed that, after migration 336 children are engaged in full time and 132 children are engaged in part time job, which are higher than the status of before migration. But rest of the 15 respondents are engage in subsidiary work which have no proper time duration before migration.

Table 5.8: Reason for Earning Among Street Children

\begin{tabular}{|l|l|l|l|l|}
\hline $\begin{array}{l}\text { Reason for Earning } \\
\text { Among } \\
\text { Children }\end{array}$ & Male & Female & $\begin{array}{l}\text { Total } \\
\text { N=468 }\end{array}$ & $\begin{array}{l}\text { Percentage } \\
(\%)\end{array}$ \\
\hline For livelihood & $120(25.64 \%)$ & $66(14.10 \%)$ & 186 & $39.74 \%$ \\
\hline $\begin{array}{l}\text { Parental } \\
\text { force/imbibed }\end{array}$ & $\mathbf{9 3}(19.87 \%)$ & $25(5.34 \%)$ & 118 & $25.21 \%$ \\
\hline For drug/Smoking & $46(9.82 \%))$ & $21(4.48 \%)$ & 67 & $14.31 \%$ \\
\hline For master & $14(2.99 \%)$ & $\mathbf{3 6}(7.69 \%)$ & 50 & $10.68 \%$ \\
\hline For education & $\mathbf{0 5}(1.06 \%)$ & $\mathbf{0 2}(0.42 \%)$ & 7 & $1.49 \%$ \\
\hline For food & $22(4.70 \%)$ & $18(3.84 \%)$ & 40 & $8.54 \%$ \\
\hline
\end{tabular}

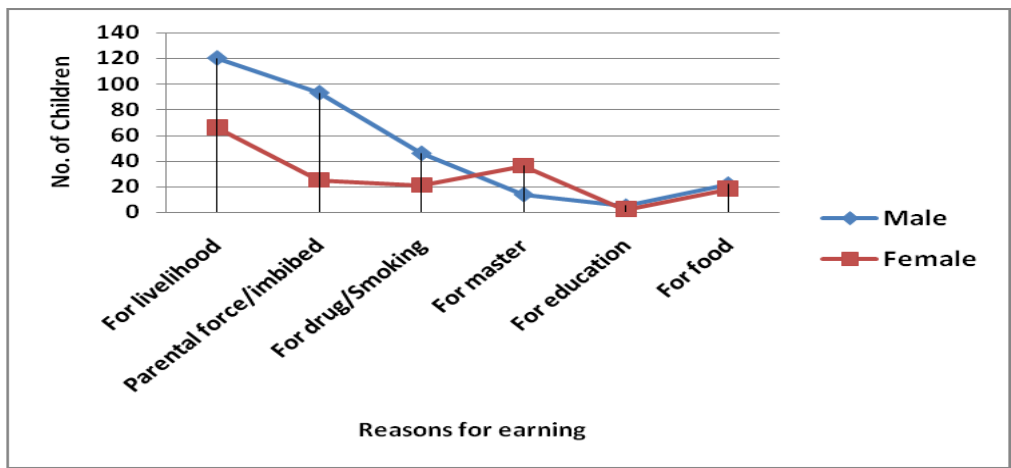

Graph 5.8: Reason for Earning Among Street Children 
Above data shown,186 children are earned money for their livelihood,118 for parental force/imbibed and 67 children earned for their addiction. Other causes i.e. for master ,education, food are seen comparatively low in children.

Table 5.9: Occupational Harassment among Street Children

\begin{tabular}{|l|l|l|l|}
\hline Pattern of Harassment & Male & Female & Total N=468 \\
\hline Physical Harassment & 186 & 74 & 260 \\
\hline Physical Abuses & 105 & 158 & 263 \\
\hline Sexual Abuse & 46 & 163 & 209 \\
\hline Mental Harassment & 142 & 201 & 343 \\
\hline Police Harassment & 256 & 189 & 445 \\
\hline Master Harassment & 29 & 46 & 75 \\
\hline Health Risk & 72 & 87 & 159 \\
\hline Life Risk & 5 & 8 & 13 \\
\hline
\end{tabular}

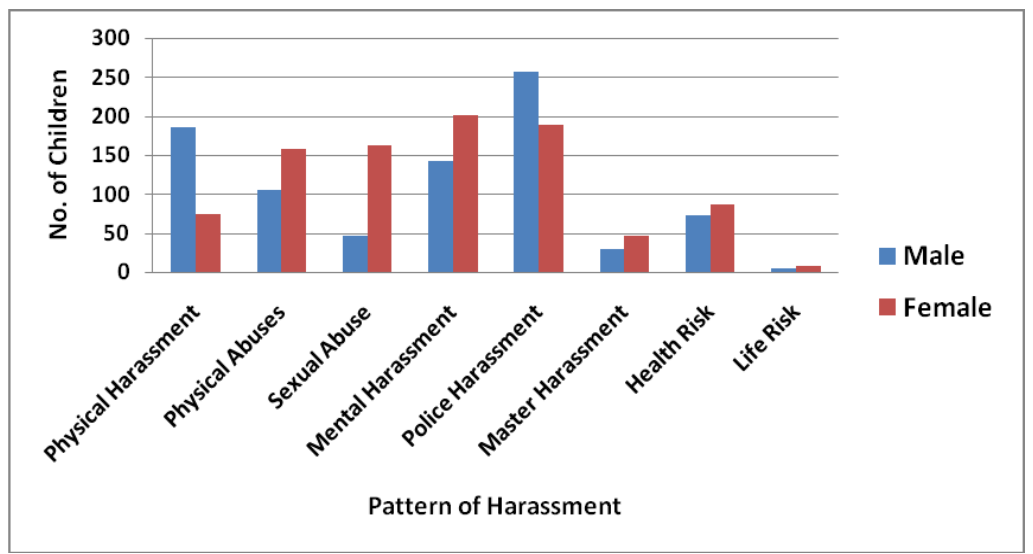

Graph 5.9: Occupational Harassment among Street Children

Above data shown the pattern of occupational harassment among street children in Kolkata. 186 male child face physical harassment, where 158 female child face physical abuse. Again, female child also face sexual and mental abuse (163 and 201 respectively) more than male child; but in case of facing police harassment ratio of the male child is high(256).

Economic Status of the Street Children According to the Family Association

Table 6.1: Family Pattern of Street Children

\begin{tabular}{|l|l|l|l|l|}
\hline Family Pattern & $\begin{array}{l}\text { Children living with the } \\
\text { family }\end{array}$ & $\begin{array}{l}\text { Children living without } \\
\text { the family }\end{array}$ & $\begin{array}{l}\text { Total } \\
\text { n=600 }\end{array}$ & Percentage \\
\hline Nuclear Family & $136(22.66 \%)$ & $73(12.16 \%)$ & 209 & $34.83 \%$ \\
\hline Joint Family & $192(32 \%)$ & $114(19 \%)$ & 306 & $51 \%$ \\
\hline Orphan & 0 & $85(14.16 \%)$ & 85 & $14.16 \%$ \\
\hline Total & $\mathbf{3 2 8}(\mathbf{5 4 . 6 6 \% )}$ & $\mathbf{2 7 2}(\mathbf{4 5 . 3 3 \% )}$ & $\mathbf{6 0 0}$ & \\
\hline
\end{tabular}

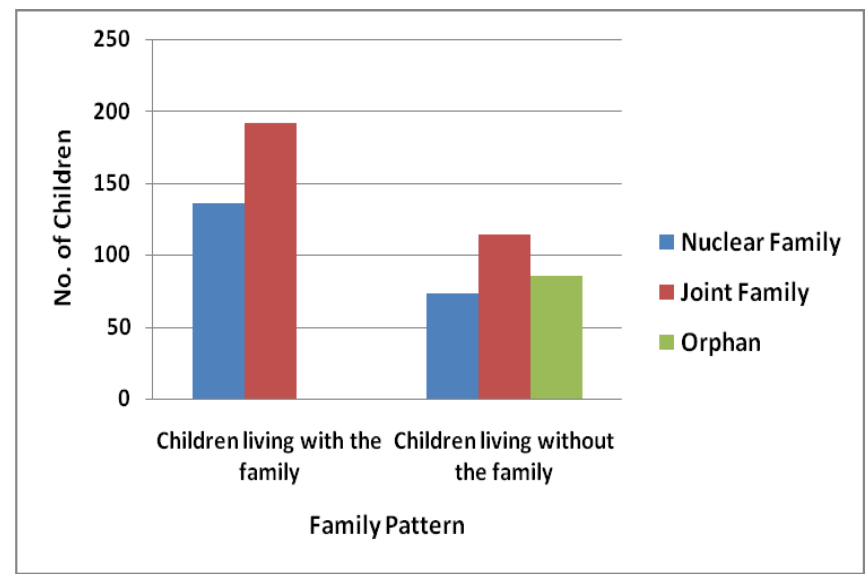

Graph 6.1: Family Pattern of Street Children 
Data reveals that, 306(51\%) children live in joint family.209 (34.83\%) live in nuclear family. Moreover, $85(14.16 \%)$ are orphan children. The majority of street children that is 328 still live with their parents which reflects the fact that, although the family system is gradually breaking down, there is still recognition of kinship in the rural areas.

Table 6.2: Number of Earning Member in a Family of Street Children

\begin{tabular}{|l|l|l|l|l|l|l|}
\hline $\begin{array}{l}\text { Number of } \\
\text { Earning } \\
\text { member }\end{array}$ & $\begin{array}{l}\text { Nuclear Family } \\
\mathbf{n = 2 0 9}\end{array}$ & $\begin{array}{l}\text { Percentage } \\
\mathbf{( \% )}\end{array}$ & $\begin{array}{l}\text { Joint Family } \\
\mathbf{n = 3 0 6}\end{array}$ & Percentage & $\begin{array}{l}\text { Orphan } \\
\mathbf{n = 8 5}\end{array}$ & $\begin{array}{l}\text { Percentage } \\
\mathbf{( \% )}\end{array}$ \\
\hline $\mathbf{1}$ & 69 & 33.01 & 164 & 53.59 & 85 & 100 \\
\hline $\mathbf{2}$ & 124 & 59.33 & 89 & 29.08 & 0 & 0 \\
\hline $\mathbf{3}$ & 16 & 7.65 & 50 & 16.33 & 0 & 0 \\
\hline $\mathbf{4}$ & 0 & 0 & 3 & 0.98 & 0 & 0 \\
\hline
\end{tabular}

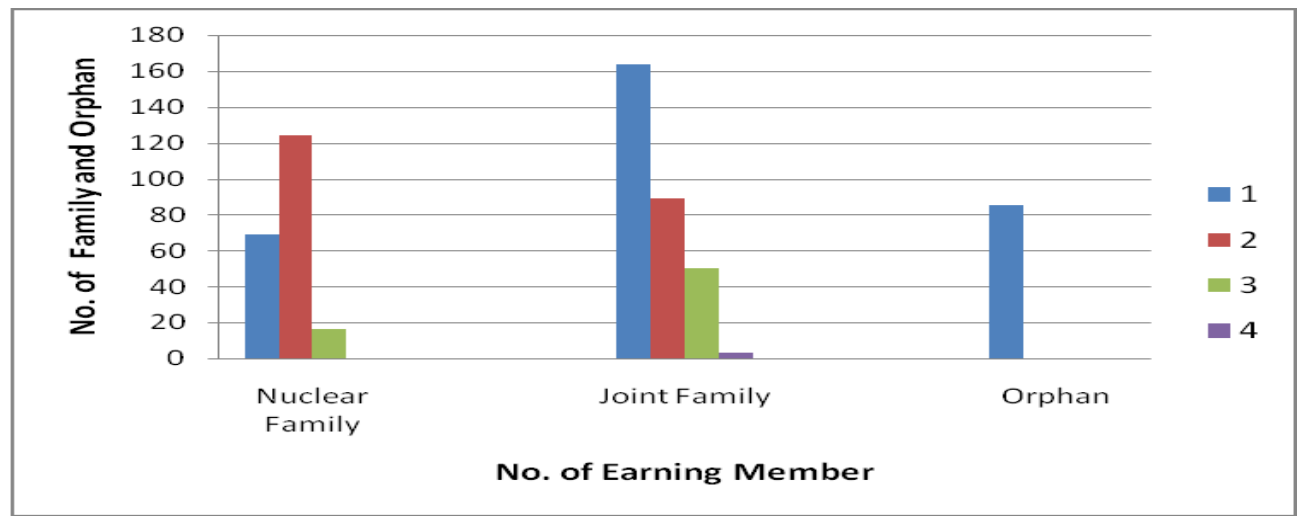

Graph 6.2: Number of Earning Member in a Family of Street Children

\section{Statistical Description:}

\begin{tabular}{|l|l|l|l|l|}
\hline Grouped Respondents & Mean & Median & Standard Deviation & Sample Variance \\
\hline Nuclear Family & 83.6 & 69 & 85.33 & 7282.3 \\
\hline Joint Family & 122.4 & 89 & 118.37 & 14013.3 \\
\hline Orphan & 34 & 30 & 32.93 & 1084.5 \\
\hline
\end{tabular}

Data shown, among the three types, in 124(59.33\%) nuclear families earning members are 2 where as in $164(53.59 \%$ )joint families ,earning member is one, Children who are living without family are consider as a orphan $(85: 100 \%)$ who earn money for their own .

Table 6.3: Range of Income of Street Children

\begin{tabular}{|l|l|l|l|l|l|}
\hline $\begin{array}{l}\text { Range of Earning, per } \\
\text { month }\end{array}$ & $\begin{array}{l}\text { Nuclear Family } \\
\mathbf{n = 2 0 9}\end{array}$ & $\begin{array}{l}\text { Joint Family } \\
\mathbf{n = 3 0 6}\end{array}$ & Orphan $\mathbf{n}=\mathbf{8 5}$ & Total $\mathbf{n = 6 0 0}$ & $\begin{array}{l}\text { Percentage } \\
(\%)\end{array}$ \\
\hline $\mathbf{5 0 0 - - 1 0 0 0}$ & 52 & 53 & 12 & 117 & 19.5 \\
\hline $\mathbf{1 0 0 1 - - 1 5 0 0}$ & 96 & 139 & 43 & 278 & 46.33 \\
\hline $\mathbf{1 5 0 1 - - 2 0 0 0}$ & 61 & 100 & 30 & 191 & 31.83 \\
\hline $\mathbf{2 0 0 1 - 5 0 0 0}$ & 0 & 14 & 0 & 14 & 2.33 \\
\hline Total & 209 & 306 & 85 & 600 & \\
\hline
\end{tabular}




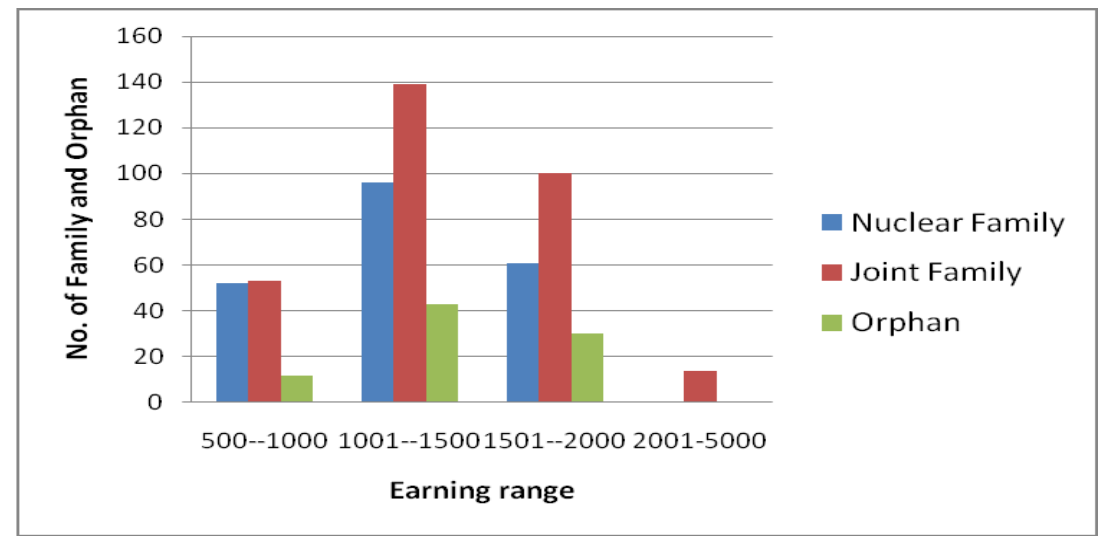

Graph 6.3 Range of Income of Street Children

Data shown, 278(46.33\%) no. of children's family's have income range from1001-1500 per month and 191(31.83\%) have from 1501-2000, in which joint, nuclear and all types of families are included and which reflect the poor economic condition of the street children.

Table 6.4: Pattern of Income in Relation with Occupation of Street Children

\begin{tabular}{|l|l|l|l|}
\hline $\begin{array}{l}\text { Pattern of Occupation } \\
\text { N=468 }\end{array}$ & Cash & Kind & Total \\
\hline Primary & $359(76.70 \%)$ & - & $359(76.70 \%)$ \\
\hline Secondary & $100(21.36 \%)$ & $05(0.83 \%)$ & $105(22.43 \%)$ \\
\hline Subsidiary & $33(7.05 \%)$ & $14(2.33 \%)$ & $47(7.83 \%)$ \\
\hline $\begin{array}{l}\text { Other Options of Earning } \\
\text { (temporary) }\end{array}$ & $\mathbf{0 2 ( 0 . 4 2 \% )}$ & $32(5.33 \%)$ & \\
\hline
\end{tabular}

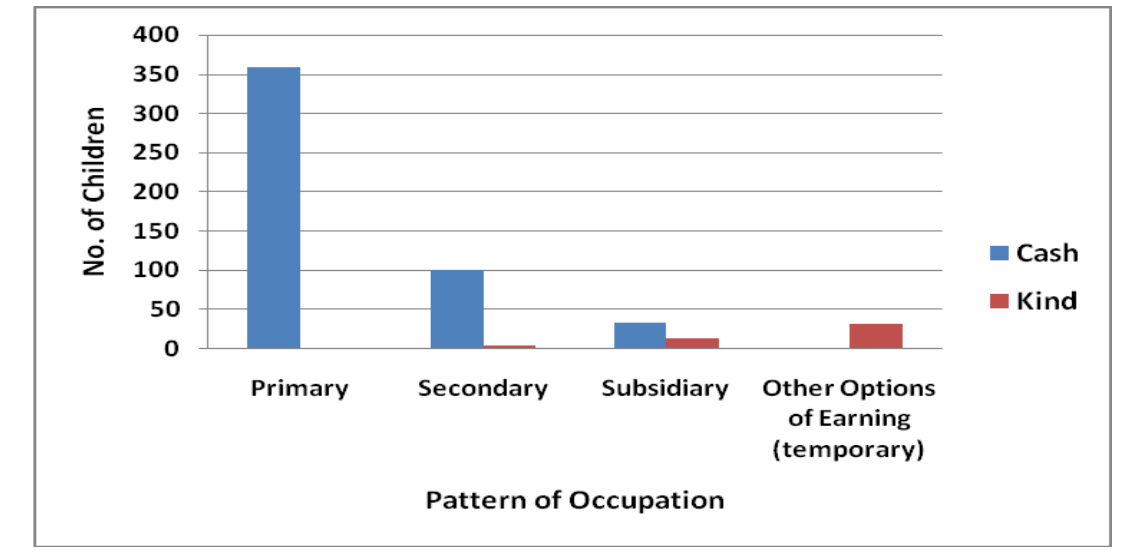

Graph 6.4: Pattern of Income in Relation with Occupation of Street Children

Data shown, maximum children in primary $(59.83 \%)$ and secondary $(17.5 \%)$ pattern of occupation are taken cash money from the employer than kind. Whereas, in temporary occupational pattern, most of the children (32) are preferring kind like food, clothes etc. than cash money who are also engaged in other pattern of occupation.

Table 6.5: Income Satisfaction among Street Children

\begin{tabular}{|l|l|l|}
\hline $\begin{array}{l}\text { Income Satisfaction } \\
\mathbf{N}=\mathbf{4 6 8}\end{array}$ & Male & Female \\
\hline Yes & $63(13.46 \%)$ & $\mathbf{8 4 ( 1 7 . 9 4 \% )}$ \\
\hline No & $182(38.88 \%)$ & $139(23.16 \%)$ \\
\hline
\end{tabular}




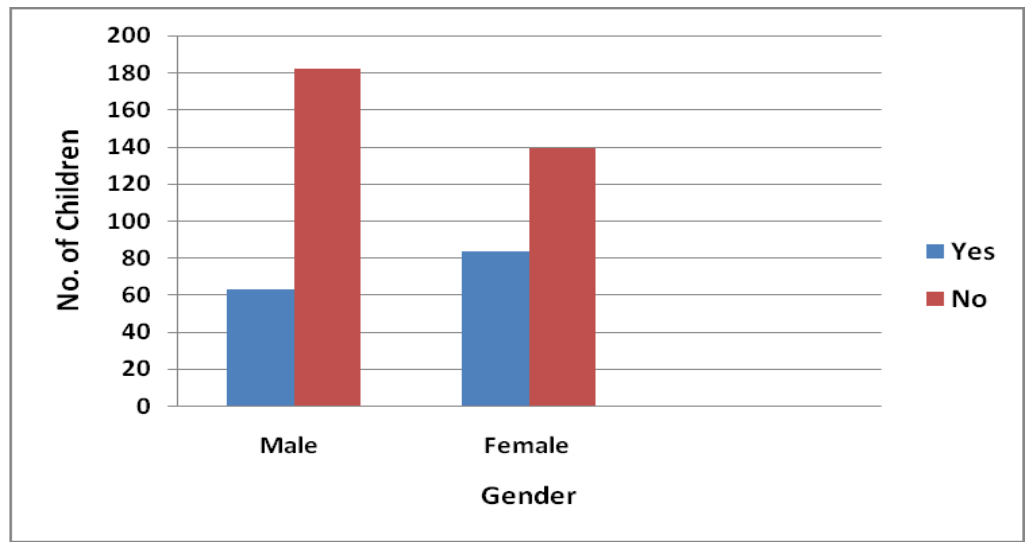

Graph 6.5: Income Satisfaction among Street Children

The income satisfaction among the children is very low. 182 male child and 139 female children are not fully satisfied with their income amount, because they could not meet their needs properly by very poor income.

\section{Migration Status among Street Children According to the Family Association}

Table 7.1: Source of Migration among Street Children

\begin{tabular}{|l|l|l|l|l|}
\hline Source of Migration & $\begin{array}{l}\text { Children living } \\
\text { with the family }\end{array}$ & $\begin{array}{l}\text { Children living } \\
\text { without the family }\end{array}$ & $\begin{array}{l}\text { Total } \\
\mathbf{n}=\mathbf{6 0 0}\end{array}$ & Percentage \\
\hline Outside West Bengal & $153(25.51 \%)$ & $139(23.16 \%)$ & 292 & 48.66 \\
\hline Outside Kolkata & $175(29.16 \%)$ & $133(22.16 \%)$ & 308 & 51.33 \\
\hline Total & $328(54.66 \%)$ & $272(45.33 \%)$ & 600 &
\end{tabular}

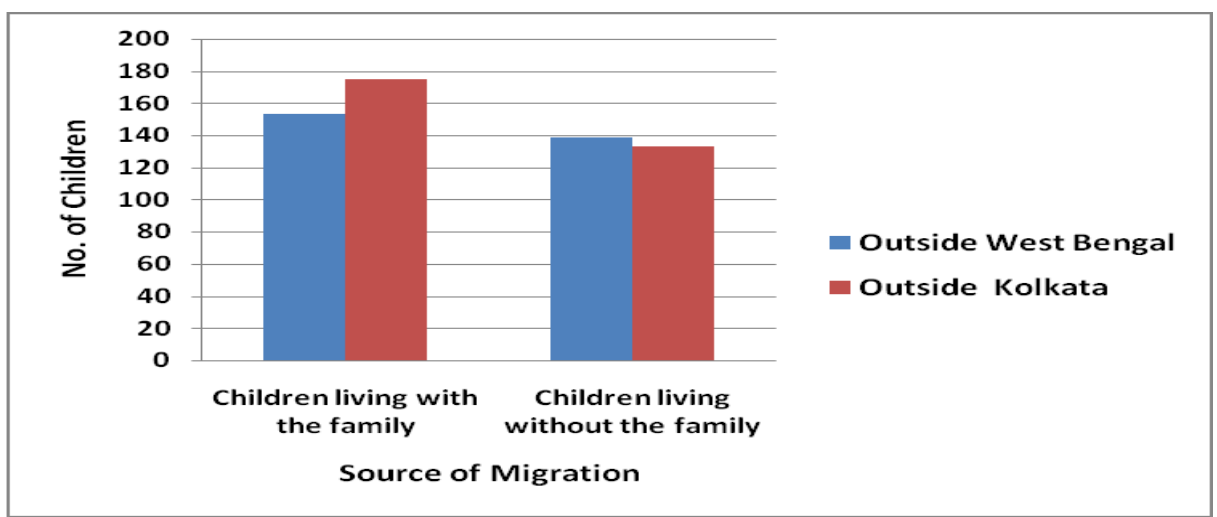

Graph 7.1 Source of Migration among Street Children

Data shown, two categories of sources of migration among the street children in Kolkata i.e. Migrated from outside of West Bengal and outside of Kolkata. The total percentage of children migrate from outside of West Bengal is $48.66 \%$ and outside of Kolkata is $51.33 \%$.

\section{Statistical Description:}

\begin{tabular}{|l|l|l|}
\hline Source Migration & Mean & Standard Deviation \\
\hline Outside West Bengal & 146 & 9.899 \\
\hline Outside Kolkata & 154 & 29.698 \\
\hline
\end{tabular}

The mean score shows that, as a source of migration, mean scores of migration from outside Kolkata is higher $(X=154)$ than outside of West Bengal $(X=146)$. 
Table 7.2: Motives of Migration among Street Children

\begin{tabular}{|c|c|c|c|c|}
\hline Motives of Migration & $\begin{array}{l}\text { Outside Kolkata } \\
\mathrm{n}=292\end{array}$ & $\begin{array}{l}\text { Percentage } \\
(\%)\end{array}$ & $\begin{array}{l}\text { Outside } \\
\text { Bengal } n=308\end{array}$ & $\begin{array}{l}\text { Percentage } \\
(\%)\end{array}$ \\
\hline $\begin{array}{llll}\text { 1. } & \text { Employment } & \text { Earn } \\
\text { money } & & & \end{array}$ & 267 & 91.43 & 278 & 90.25 \\
\hline $\begin{array}{lcc}2 . & \text { Assorted } & \text { family } \\
\text { problems including abuse } & \end{array}$ & 121 & 41.43 & 187 & 60.71 \\
\hline Lack of home/ Family & 43 & 14.72 & 42 & 13.63 \\
\hline $\begin{array}{llll}4 . \quad \text { Imitation of } & \text { Friend/ } \\
\text { Peer } & \text { Pressure } & & \\
\end{array}$ & 118 & 40.41 & 27 & 8.76 \\
\hline 5. To Avoid School & 71 & 24.31 & 53 & 17.20 \\
\hline $\begin{array}{l}\text { 6. Lack of Opportunity } \\
\text { for Education }\end{array}$ & 32 & 10.95 & 16 & 5.19 \\
\hline City Life Attraction & 105 & 35.95 & 108 & 35.06 \\
\hline Force from Home & 187 & 64.04 & 98 & 31.81 \\
\hline $\begin{array}{l}\text { 9. Suffering due to social } \\
\text { environment / practice }\end{array}$ & 63 & 21.57 & 92 & 29.87 \\
\hline
\end{tabular}

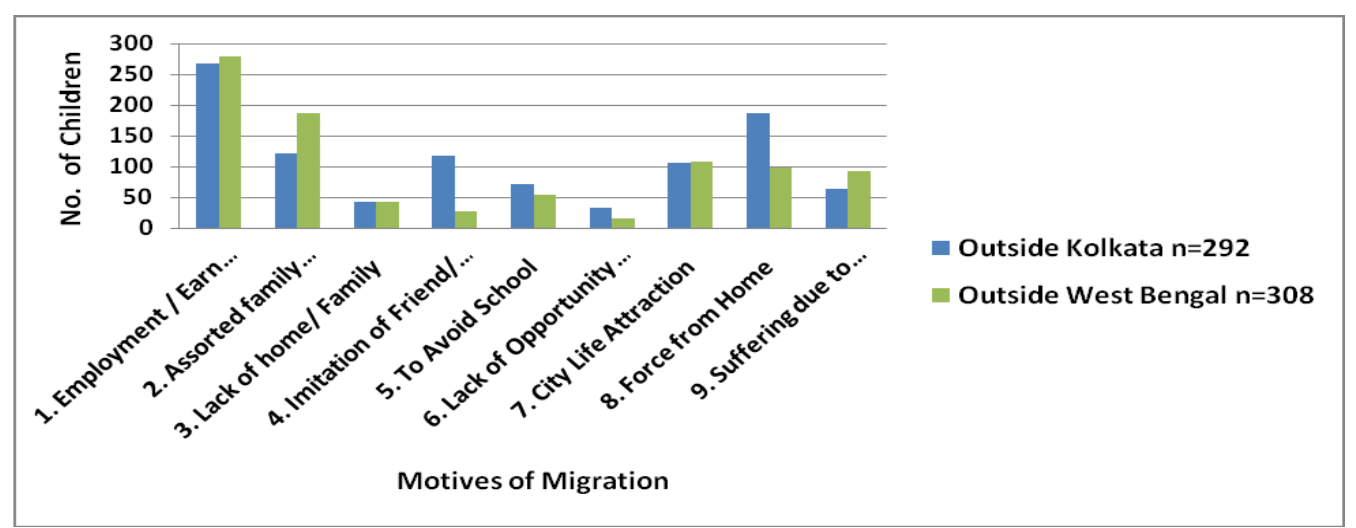

Graph 7.2: Motives of Migration among Street Children

Above data shown, motivational causes mainly important and responsible for migration from outside West Bengal and Kolkata to streets of Kolkata. Among these, to earn money 267(91.43\%), force from home 187(64.04\%), assorted family problems including abuse $121 \quad(41.43 \%)$ children were migrated from outside Kolkata to streets of Kolkata. Simultaneously, children migrated from outside West Bengal to streets of Kolkata to earning money 278 (90.25\%), Assorted family problems including abuse $187(60.71 \%)$.

\section{Statistical Description:}

\begin{tabular}{|l|l|l|l|}
\hline Motives of Migration & Mean & $\begin{array}{l}\text { Standard } \\
\text { Deviation }\end{array}$ & $\begin{array}{l}\text { Sample } \\
\text { Variance }\end{array}$ \\
\hline Employment / Earn money & 272.5 & 7.778174593 & 60.5 \\
\hline $\begin{array}{l}\text { Assorted family problems including } \\
\text { abuse }\end{array}$ & 154 & 46.66904756 & 2178 \\
\hline Lack of home/ Family & 42.5 & 0.707106781 & 0.5 \\
\hline Imitation of Friend/ Peer Pressure & 72.5 & 64.34671709 & 4140.5 \\
\hline Avoiding School & 62 & 12.72792 & 162 \\
\hline Lack of Opportunity for Education & 24 & 11.31371 & 128 \\
\hline City Life Attraction & 106.5 & 2.12132 & 4.5 \\
\hline Force from Home & 142.5 & 62.9325 & 3960.5 \\
\hline $\begin{array}{l}\text { Suffering due to social environment } \\
\text { / practice }\end{array}$ & 77.5 & 20.5061 & 420.5 \\
\hline
\end{tabular}

The mean score of the motives of migration to streets of Kolkata shows that, earning money have a higher mean score $(X=272.5)$ and the Assorted family problems including abuse also have high mean $\operatorname{score}(X=154)$ than the rest of the motives. 
Table 7. 3: Causes of Migration among Street Children

The

\begin{tabular}{|l|l|l|l|l|}
\hline Causes & $\begin{array}{l}\text { Male } \\
\mathbf{N = 3 9 2}\end{array}$ & $\begin{array}{l}\text { Female } \\
\mathbf{N = 2 0 8}\end{array}$ & $\begin{array}{l}\text { Total } \\
\mathbf{N = 6 0 0}\end{array}$ & $\begin{array}{l}\text { Percentage } \\
\mathbf{( \% )}\end{array}$ \\
\hline Poverty & $277(70.66 \%)$ & $196(94.23 \%)$ & 473 & 78.83 \\
\hline Assorted family problems including abuse & $192(48.97 \%)$ & $116(55.76 \%)$ & 308 & 51.33 \\
\hline Follow friends / peer pressure & $84(21.42 \%)$ & $61(29.32 \%)$ & 145 & 24.16 \\
\hline Attraction of city life & $110(28.06 \%)$ & $103(49.51 \%)$ & 213 & 35.5 \\
\hline Family / Parent marriage break down & $92(23.46 \%)$ & $63(30.28 \%)$ & 155 & 25.83 \\
\hline Unjust community structures and practices & $12(3.06 \%)$ & $19(9.13 \%)$ & 31 & 5.16 \\
\hline Boredom at home and in the community & $45(11.47 \%)$ & $22(10.57 \%)$ & 67 & 11.16 \\
\hline To work for money & $285(72.70 \%)$ & $208(100 \%)$ & 543 & 90.5 \\
\hline Lack of home / family & $190(48.46 \%)$ & $91(43.75 \%)$ & 281 & 46.83 \\
\hline Avoiding school & $86(21.93 \%)$ & $38(18.26 \%)$ & 124 & 20.66 \\
\hline Step parenting & $21(5.35 \%)$ & $13(6.25 \%)$ & 34 & 5.66 \\
\hline Illiterate parents & $115(29.33 \%)$ & $78(37.5 \%)$ & 193 & 32.16 \\
\hline Restrict Education & $07(1.78 \%)$ & $02(0.96 \%)$ & 9 & 1.5 \\
\hline Other cause & $04(1.02 \%)$ & $02(0.96 \%)$ & 6 & 1 \\
\hline
\end{tabular}

above table shows, to work for money $(90.5 \%)$, poverty $(78.83 \%)$, assorted family problems including abuse $(51.33 \%)$ are the main causes for migration found amongst street children in Kolkata.

Table 7.4: Causal Factors of Migration among Street Children

\begin{tabular}{|l|l|l|l|l|l|}
\hline Causal Factors of Migration & $\begin{array}{l}\text { Children } \\
\text { living with } \\
\text { the family } \\
\text { n=328 }\end{array}$ & Pull & Percentage & $\begin{array}{l}\text { Children living } \\
\text { without the } \\
\text { family n=272 }\end{array}$ & Percentage \\
\hline $\begin{array}{l}\text { Poverty \& ill } \\
\text { environment }\end{array}$ & Prosperity & 315 & 96.03 & 243 & 89.33 \\
\hline $\begin{array}{l}\text { Lack of Education \& } \\
\text { Awareness }\end{array}$ & Opportunity & 66 & 20.12 & 46 & 16.91 \\
\hline Unemployment & Employment & 289 & 88.1 & 263 & 96.69 \\
\hline
\end{tabular}

In the above table, causal factors of migration are stated as push factor and pull factor. Most Children living without family because of unemployment in previous places is 263(96.69\%) and children living with family and migrated to Kolkata for poverty and ill environment is $315(96.03 \%)$.

Statistical Description:

\begin{tabular}{|l|l|l|l|l|}
\hline Causal Factors of Migration & Mean & Standard Deviation & Sample Variance \\
\hline Push Poverty \& ill environment & Prosperity & 279 & 50.91 & 2592 \\
\hline $\begin{array}{l}\text { Lack of Education \& } \\
\text { Awareness }\end{array}$ & Opportunity & 56 & 14.14 & 200 \\
\hline Unemployment & Employment & 276 & 18.38 & 338 \\
\hline
\end{tabular}

Among the causal factors of migration, the mean scores for poverty \& ill environment and prosperity is 279; unemployment and employment is 276 which do not significantly differ.

Table 7.5: Problems Faced by Street Children due to Migration

\begin{tabular}{|l|l|l|l|l|}
\hline Problems Due to Migration & $\begin{array}{l}\text { According Informant } \\
\mathbf{n = 9 8}\end{array}$ & $\begin{array}{l}\text { Percentage } \\
\mathbf{( \% )}\end{array}$ & $\begin{array}{l}\text { According } \\
\text { Children n=502 }\end{array}$ & $\begin{array}{l}\text { Percentage } \\
\mathbf{( \% )}\end{array}$ \\
\hline Shelter & 87 & 88.78 & 462 & 92.03 \\
\hline Water & 98 & 100 & 432 & 86.06 \\
\hline Food & 91 & 92.86 & 489 & 97.41 \\
\hline Clothing & 34 & 34.69 & 267 & 53.19 \\
\hline Health & 22 & 22.45 & 156 & 31.08 \\
\hline Electricity & 8 & 8.16 & 490 & 97.61 \\
\hline Washroom & 94.90 & 491 & 97.81 \\
\hline Education & 93 & 32.65 & 200 & 39.84 \\
\hline Employment Opportunity & 32 & 90.82 & 43 & 8.57 \\
\hline Change of Weather & 89 & 88.78 & 462 & 92.03 \\
\hline Natural Calamities & 87 & 34.69 & 143 & 28.49 \\
\hline
\end{tabular}

Informant and children both are facing many problems till now after migration to the streets of Kolkata . Children ages 5-16 years are staying on the streets / footpath with shelter problems 92.03\% (462) ,with noaccess to water $86.06 \%$ (432), not getting proper food $97.41 \%$ (489), problems of washrooms 97.81 (491), 
problems during change of weather $92.03 \%$ (462). The children ages $2-4$ years who are informants, face other problems too along with those mentioned above.

Table 7.6: Reasons for not leaving the Street

\begin{tabular}{|l|l|l|l|l|}
\hline $\begin{array}{l}\text { Reason for not leaving } \\
\text { Kolkata }\end{array}$ & $\begin{array}{l}\text { Male } \\
\text { N=392 }\end{array}$ & $\begin{array}{l}\text { Female } \\
\text { N=208 }\end{array}$ & Total & Percentage \\
\hline Helpless & $56(14.28 \%)$ & $29(13.94 \%)$ & 85 & 14.16 \\
\hline With parents & $214(54.59 \%)$ & $115(55.28 \%)$ & 329 & 54.83 \\
\hline Comfort & $12(3.06 \%)$ & $04(1.92 \%)$ & 16 & 2.66 \\
\hline Workplace & $247(63.01 \%)$ & $189(90.86 \%)$ & 436 & 72.66 \\
\hline Savings & $02(0.51 \%)$ & $09(4.32 \%)$ & 11 & 1.83 \\
\hline Easy to go back home & $87(22.19 \%)$ & $46(22.11 \%)$ & 133 & 22.16 \\
\hline With peer & $325(82.90)$ & $167(80.28 \%)$ & 492 & 82 \\
\hline
\end{tabular}

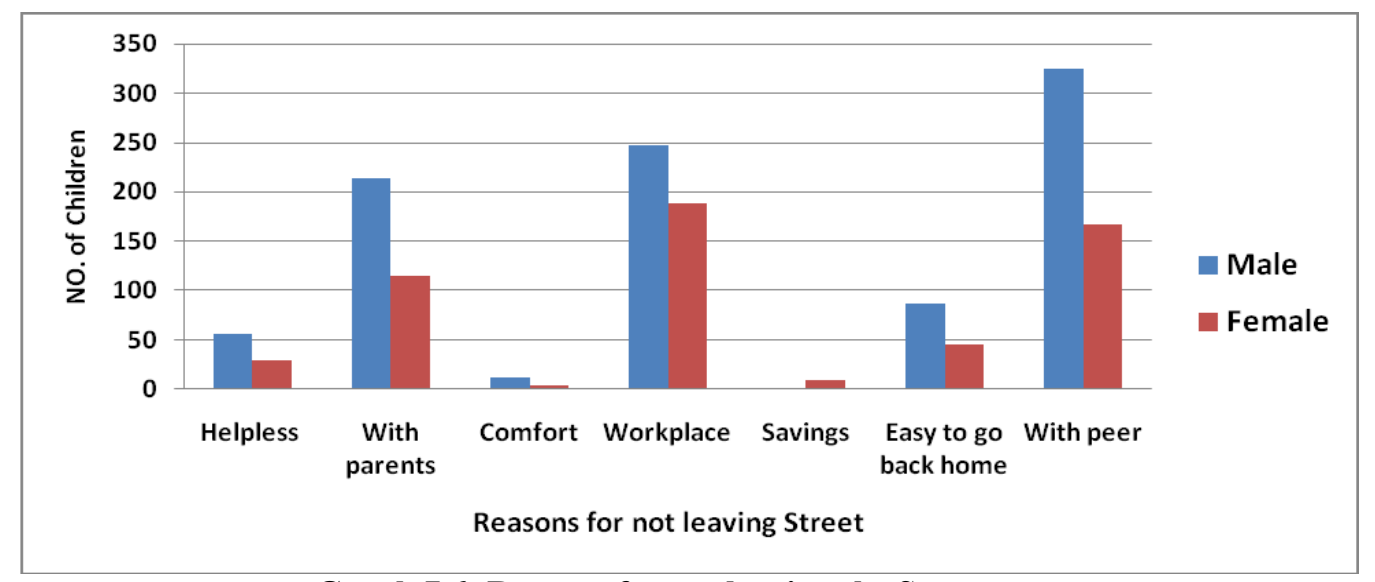

Graph 7.6: Reasons for not leaving the Street

Table 7.7: Expected Resolution of Migration among Street Children

\begin{tabular}{|l|l|l|l|}
\hline Expected Resolution of Migration & Access & Not able to access & Not aware of \\
\hline Awas Yojna of Government & $2(0.33 \%)$ & $85(14.16 \%)$ & $513(85.5 \%)$ \\
\hline Assistance of House Making & 0 & $87(14.5 \%)$ & $513(85.5 \%)$ \\
\hline $\begin{array}{l}\text { Use of tube well / Well \& Drinking } \\
\text { Water }\end{array}$ & $425(70.83 \%)$ & $5(0.83 \%)$ & $170(28.33 \%)$ \\
\hline Ration System for all below BPL & $6(1 \%)$ & $133(22.16 \%)$ & $461(76.83 \%)$ \\
\hline Free Education & $155(25.83 \%)$ & $70(11.66 \%)$ & $375(62.5 \%)$ \\
\hline $\begin{array}{l}\text { Employment Opportunity at their native } \\
\text { place }\end{array}$ & $15(2.5 \%)$ & $18(3 \%)$ & $567(94.5 \%)$ \\
\hline \begin{tabular}{l} 
Self Help Program at native place \\
\hline
\end{tabular} & $3(0.5 \%)$ & $4(0.66 \%)$ & $593(98.83 \%)$ \\
\hline
\end{tabular}

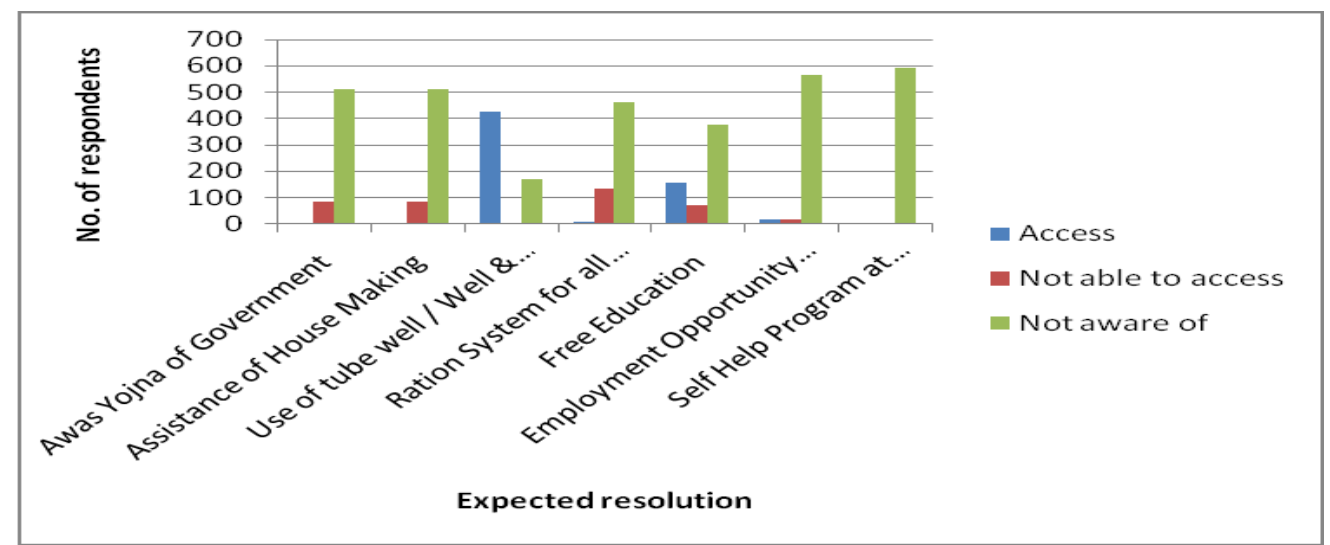

Graph 7.7: Expected Resolution of Migration among Street Children

Data shown that, among 600 children 462 are not aware about the Awash yojona of Govt. only 2 children can access where as 85 children know about it but they cannot access it due to many rules and regulation. In the category, access of services provide by govt. (corporation), maximum street children (425) 
can use tube well for drinking water. On the other hand, in Ration System for all below BPL 133 children are not able to access it and 421 children don't know about this. Same is true in the assistance for house making where 462 children are not aware of it.

Hypothesis 1: There is significant difference in social status in terms of the living pattern of the children living with the family and without family

\begin{tabular}{|l|l|l|}
\hline $\begin{array}{l}\text { Social Status as per Living } \\
\text { Condition }\end{array}$ & Children living with the family & $\begin{array}{l}\text { Children living without the } \\
\text { family }\end{array}$ \\
\hline Permanent house & 14 & 2 \\
\hline Temporary house & 243 & 186 \\
\hline Temporary house on street & 53 & 12 \\
\hline Homeless & 18 & 72 \\
\hline
\end{tabular}

\begin{tabular}{|l|l|}
\hline $\mathrm{P}(\mathrm{T}<=\mathrm{t})$ two-tail & 0.008045672 \\
\hline $\mathrm{t}$ Critical two-tail & 2.446911851 \\
\hline
\end{tabular}

Since, $\mathrm{P}$ is .008 for two tails, i.e. $<0.05$ the above hypothesis has been rejected at $5 \%$ level of significance.

Therefore, there is no significant difference in social status in terms of the living pattern of the children living with the family and without family.

Hypothesis 2: There is significant difference in economic status in terms of the monthly income of the children belonging to nuclear and joint family.

\begin{tabular}{|l|l|l|}
\hline $\begin{array}{l}\text { Economic Status as per monthly } \\
\text { income }\end{array}$ & $\begin{array}{l}\text { Nuclear Family } \\
\mathrm{n}=209\end{array}$ & $\begin{array}{l}\text { Joint Family } \\
\mathrm{n}=306\end{array}$ \\
\hline $500--1000$ & 52 & 53 \\
\hline $1001--1500$ & 96 & 139 \\
\hline $1501--2000$ & 61 & 100 \\
\hline $2001-5000$ & 0 & 14 \\
\hline
\end{tabular}

\begin{tabular}{|l|l|}
\hline $\mathrm{P}(\mathrm{T}<=\mathrm{t})$ two-tail & 0.094997223 \\
\hline $\mathrm{t}$ Critical two-tail & 3.182446305 \\
\hline
\end{tabular}

Since, $\mathrm{P}$ is .094 for two tails, i.e. $>0.05$ the above hypothesis has been accepted at $5 \%$ level of significance.

Therefore, there is significant difference in economic status in terms of the monthly income of the children belonging to nuclear and joint family.

Hypothesis 3: There is significant difference in economic status in terms of the monthly income of the children belonging to nuclear family and orphans.

\begin{tabular}{|l|l|l|}
\hline Range of Earning, per month & $\begin{array}{l}\text { Nuclear Family } \\
\mathrm{n}=209\end{array}$ & Orphan $\mathrm{n}=85$ \\
\hline $500--1000$ & 52 & 12 \\
\hline $1001--1500$ & 96 & 43 \\
\hline $1501--2000$ & 61 & 30 \\
\hline $2001-5000$ & 0 & 0 \\
\hline
\end{tabular}

\begin{tabular}{|l|l|}
\hline $\mathrm{P}(\mathrm{T}<=\mathrm{t})$ two-tail & 0.070801463 \\
\hline $\mathrm{t}$ Critical two-tail & 3.182446305 \\
\hline
\end{tabular}
significance.

Since, $\mathrm{P}$ is .070 for two tails, i.e. $>0.05$ the above hypothesis has been accepted at $5 \%$ level of

Therefore, there is significant difference in economic status in terms of their monthly income of the children belonging to nuclear family and orphans.

Hypothesis 4: There is significant difference in economic status in terms of the monthly income of the children belonging to joint family and orphans. 


\begin{tabular}{|l|l|l|}
\hline Range of Earning, per month & $\begin{array}{l}\text { Joint Family } \\
\mathrm{n}=306\end{array}$ & Orphan $\mathrm{n}=85$ \\
\hline $500--1000$ & 53 & 12 \\
\hline $1001--1500$ & 139 & 43 \\
\hline $1501--2000$ & 100 & 30 \\
\hline $2001-5000$ & 14 & 0 \\
\hline
\end{tabular}

\begin{tabular}{|l|l|}
\hline $\mathrm{P}(\mathrm{T}<=\mathrm{t})$ two-tail & 0.052805239 \\
\hline $\mathrm{t}$ Critical two-tail & 3.182446305 \\
\hline
\end{tabular}

Since, $\mathrm{P}$ is .052 for two tails, i.e. $>0.05$ the above hypothesis has been accepted at $5 \%$ level of significance.

Therefore, there is significant difference in economic status in terms of the monthly income of the children belonging to joint family and orphans.

Hypothesis 5: There is no significant difference in the motives of migration to the streets of Kolkata among the children coming from the areas outside Kolkata and West Bengal.

\begin{tabular}{|l|l|l|}
\hline Motives of Migration to Kolkata Street & $\begin{array}{l}\text { Outside Kolkata } \\
\mathrm{n}=292\end{array}$ & $\begin{array}{l}\text { Outside West Bengal } \\
\mathrm{n}=308\end{array}$ \\
\hline Employment / Earn money & 267 & 278 \\
\hline Assorted family problems including abuse & 121 & 187 \\
\hline Lack of home/ Family & 43 & 42 \\
\hline Imitation of Friend/ Peer Pressure & 118 & 27 \\
\hline To avoid School & 71 & 53 \\
\hline Lack of Opportunity for Education & 32 & 16 \\
\hline City Life Attraction & 105 & 108 \\
\hline Force from Home & 187 & 98 \\
\hline $\begin{array}{l}\text { Suffering due to social environment / } \\
\text { practice }\end{array}$ & 63 & 92 \\
\hline
\end{tabular}

\begin{tabular}{|c|l|}
\hline $\mathrm{P}(\mathrm{T}<=\mathrm{t})$ two-tail & 0.508567289 \\
\hline $\mathrm{t}$ Critical two-tail & 2.306004135 \\
\hline
\end{tabular}
significance.

Since, $\mathrm{P}$ is .050 for two tails, i.e. $>0.05$ the above hypothesis has been accepted at $5 \%$ level of

Therefore, there is no significant difference in the motives of migration to the streets of Kolkata among the children coming from the areas outside Kolkata and West Bengal.

Hypothesis 6: There is no significant difference in causal factor of migration among the children living with and without the family.

\begin{tabular}{|l|l|l|}
\hline Cause of Migration & $\begin{array}{l}\text { Children living with the } \\
\text { family } \mathrm{n}=328\end{array}$ & $\begin{array}{l}\text { Children living without the } \\
\text { family } \mathrm{n}=272\end{array}$ \\
\hline Poverty \& ill environment vs. Prosperity & 315 & 243 \\
\hline Lack of Education \& Awareness vs. Opportunity & 66 & 46 \\
\hline Unemployment vs. employment & 289 & 263 \\
\hline
\end{tabular}

\begin{tabular}{|l|l|}
\hline $\mathrm{P}(\mathrm{T}<=\mathrm{t})$ two-tail & 0.03923837 \\
\hline $\mathrm{t}$ Critical two-tail & 3.182446305 \\
\hline
\end{tabular}
significance.

Since, $\mathrm{P}$ is .039 for two tails, i.e. $<0.05$ the above hypothesis has been rejected at $5 \%$ level of Therefore, there is significant difference in causal factors of migration among the children living with and without the family. 


\section{Correlation}

Hypothesis No. 7: The variables are positively correlated, i.e. Street Children are positively correlated to Migration \& Poverty.

\begin{tabular}{|l|l|l|l|}
\hline Variables & Street Children $(X)$ & Migration $(Y)$ & Poverty $(Z)$ \\
\hline Street Children $(X)$ & 1 & 0.981 & 0.954 \\
\hline Migration $(Y)$ & 0.981 & 1 & 0.922 \\
\hline Poverty $(Z)$ & 0.954 & 0.922 & 1 \\
\hline
\end{tabular}

Analysis: Correlations among all the 3 variables were computed through Pearson's Product Moment method. It was aimed at examining the degree of association between the measures of Street Children, Migration and Poverty. A careful inspection of inter-correlation matrix (Table - 8) reveals that all the variables correlate significantly with each other. The inter-correlation between Street Children and Migration is positively corelated 0.981 , which is significant at 0.05 probability level. It shows that increase in street children indicate increase number of migration into Kolkata street. It can also be said that the migration can be the root cause of problem of street children in Kolkata. The correlation between the measures of Migration and Poverty rate is also significant. The inter correlation between both is 0.922 , which is significant at 0.05 probability level. Here the correlation between both is positive and significant which shows that the people or the children come on the street of Kolkata through migration intended to leave the poverty life because of the trap of vicious circle, so it can be said that there is a positive association between them. The correlation between Street Children and Poverty is positively related as 0.954 which is also significant at 0.05 probability level. It shows that children who are migrated to the streets of Kolkata are having high probability to live.

\section{Regression}

Hypothesis No. 8: The factor Street Children at Kolkata is directly attributed to migration.

\begin{tabular}{|l|l|l|l|l|l|}
\hline Multiple R & $\mathbf{0 . 9 8}$ & & df & SS & MS \\
\hline R Square & $\mathbf{0 . 9 8}$ & Regression & 2 & 9715.38 & 9715.38 \\
\hline Adjusted R Square & $\mathbf{0 . 9 7}$ & Residual & 2 & 66.61 & 66.61 \\
\hline Standard Error & $\mathbf{8 . 1 6}$ & F & 145.85 & P & $<.005$ \\
\hline
\end{tabular}

Regression analysis was computed to assess the strength of relationship between dependent variable and independent variables. The results of regression analysis for the dependent variable Street Children presented in table 9 indicate that the migration as independent variable influences the former. In Overall both the predictors contributed Multiple R of .98. The F ratio computed for the significance of multiple R is 145.85 , which is significant at .005 probability level. Therefore, migration is directly attributed to the problem of street children at Kolkata.

\section{Findings and Analysis}

The study revealed that, the absolute and relative size of the population of children in India is quite big as a share of the national population, in which street children also included as mentioned previous (Page:2).

It was identified by the researcher that, majority of street children $(32 \%)$ were within $8-10$ yrs. with more males(65.33\%) than females(34.66\%).Up to $71.66 \%$ were literate including high drop-out(53.95\%) while $28.33 \%$ were illiterate.

Beside these, important findings are can be categorized in to three(3) categories -

1)Social status,

2)Economical status,

3)Causal factors and influencing factors of Migration.

- Social status included living pattern of street children living with or without family. $71.5 \%$ children with or without family live in temporary houses on street made with only tent like plastics where as $15 \%$ are completely homeless, who are roaming around and searching for livelihood. On the pavement or road side or under the bridge few of these families $(2.66 \%)$ live in permanent shelter made with bamboo, old jute pieces, plastic etc., hook electricity to run some electronics appliances like, T.V, radio etc. Using of some house hold acquaintance like broken dressing-table, trunk, Chula, cycle, utensils etc. also seen in them.

- $\quad$ Family pattern, number of earning members and range of income are included in Economical status of street children in Kolkata. The majority of street children (328) still live with their family in which rate of association of joint family were high(51\%) than nuclear family(34.83\%). As per findings, the economic status of nuclear family, joint family and orphan have significant difference in terms of monthly income along with earning members. In maximum nuclear family(59.33\%) earning members are two where as maximum joint family(53.59\%) run by one bread earner. Along with this, maximum nuclear(96),joint(139) families and also 
orphan(43)'s monthly income range were 1001-1500; wich is shown much more difficulties in joint families than other two because of more family members.

Economic status is inter-related with occupational status of street children in where it can be seen that,78\%(468)children were child labor, engaged in non-hazardous $(62.39 \%)$ pattern of work more than hazardous(37\%)patterns. Many children engaged in begging, car-washing, selling goods on streets, which were consider as non-hazardous; in contrast some were also involved with cinema ticket blacking, substance peddling, prostitution as a hazardous working patterns.

- Sources of migration can be divided in to two categories - out side from West Bengal and outside from Kolkata. Study shown that maximum children with or without family(51.33\%) migrated to Kolkata street outside from Kolkata than outside from West Bengal(48.66\%). But there is no significant difference in motives of migration to Kolkata street between both sources. As an important motives of migration earning money, assorted family problems, imitation of friends, city life attraction, force from home are mostly seen in the street children. Which is also correlated with the causal-factors of migration. The causes of migration is described as an interaction of "push" and "pull" factors. The leading causes of the migration of children with or without family are poverty\& ill environment (96.03\%;89.33\% respectively), unemployment $(88.1 \% ; 96.69 \%$ respectively) than lack of education\& awareness of opportunity.

On the basis of 40 pilot study, the problem faced by the respondent for the migration are identified and ranked in decreasing order of frequency of appearance of each problems, in which problem of shelter (Informant:88.78\%; Children:92.03\%), accesses of water (Informant: 100\%; Children: 86.06\%),Food (Informant: 92.86\%; Children: 97.41\%) and change of Weather(Informant:88.78\%;children:92.03\%) are seen as a major factor for street children.

In order to survive the street children, they need to reside in areas with a special supportive environment and characteristics that do not conflict with their life-style, nor pose threats against their existence. To solve the problems of migration they should know the scheme and services provided by the Government and NGO's. But the study shown that, only small proportion of children can access Awas Yojna, Ration system, Self Help Program where as out of 600,425 are not aware about these services. They more or less access only Free education (155) and drinking water from tube-well (425).

The present study can be summarized with the inference that policies and action to reduce street migration by children will need to drop the non-income form of poverty along with material poverty. These children are victims of the socio-economic conjuncture of the country which often leads to the break up of families. Girls, either married at a very young age or then abandoned but quickly taken into the prostitution network, are in lesser numbers on the streets than the boys.

In a constant struggle to live, these children have to use any and whatever means possible to survive : begging, stealing, sweeping trains, polishing shoes, etc., threats from the older children, rejection from society, rape, sickness, drugs, prostitution... With a desperate need to keep moving and be free. They do not even have an inclination to think about their futures. Their day starts on the streets and ends on the same street.

The study revealed that, the absolute and relative size of the population of children in India is quite big as a share of the national population, in which street children included as mentioned previous (Page:2).

It was identified by the researcher that, majority of street children $(32 \%)$ were within $8-10$ yrs. with more males $(65.33 \%)$ than females(34.66\%).Up to $71.66 \%$ were literate including high drop-out $(53.95 \%)$ while $28.33 \%$ were illiterate.

The independent variables contributing the dependent variable i.e. street children are indentified as three (3) factors -

1) Social and educational status factor,

2) Economical status factor,

3) Causal factors and factors influencing migration.

- Social status included living pattern of street children living with or without family. Children with or without family live in temporary houses on street made with only tent like plastics are $71.5 \%$, where as $15 \%$ are completely homeless, who are roaming around and searching for livelihood. On the pavement or road side or under the bridge few of these families $(2.66 \%)$ live in permanent shelter made with bamboo, old jute pieces, plastic etc., hook electricity to run some electronics appliances like, T.V, radio etc. Using of some house hold acquaintance like broken dressing-table, trunk, Chula, cycle, utensils etc. also seen in them.

Family pattern, number of earning members and range of income are included in Economical status of street children in Kolkata. The majority of street children (328) still live with their family in which rate of association of joint family were high (51\%) than nuclear family $(34.83 \%)$. As per findings, the economic status of nuclear family, joint family and orphan have significant difference in terms of monthly income along with earning members. In maximum nuclear family $(59.33 \%)$ earning members are two where as maximum joint family (53.59\%) run by one bread earner. Along with this, maximum nuclear (96), joint (139) families and also 
orphan(43)'s monthly income range were 1001-1500; wich is shown much more difficulties in joint families than other two because of more family members.

- $\quad$ Economic status is inter-related with occupational status of street children in where it can be seen that, $78 \%$ (468) children were child labor, engaged in non-hazardous $(62.39 \%)$ pattern of work more than hazardous (37\%) patterns. Many children engaged in begging, car-washing, selling goods on streets, which were consider as non-hazardous; in contrast some were also involved with cinema ticket blacking, substance peddling and prostitution as a hazardous working patterns.

- Sources of migration can be divided in to two categories - out side from West Bengal and outside from Kolkata. Study shown that maximum children with or without family $(51.33 \%)$ migrated to Kolkata street outside from Kolkata than outside from West Bengal (48.66\%). But there is no significant difference in motives of migration to Kolkata Street between both sources. Earning money is an important motive of migration, assorted family problems, imitation of friends, city life attraction and force from home are mostly seen in the street children, which is also correlated with the causal-factors of migration. The causes of migration are described as an interaction of "push" and "pull" factors. The leading causes of the migration of children with or without family are poverty\& ill environment $(96.03 \% ; 89.33 \%$ respectively), unemployment $(88.1 \% ; 96.69 \%$ respectively) than lack of education \& awareness of opportunity.

On the basis of 40 pilot study, the problem faced by the respondent for the migration are identified and ranked in decreasing order of frequency of appearance of each problems, in which problem of shelter (Informant: 88.78\%; Children: 92.03\%), accesses of water (Informant: 100\%; Children: 86.06\%), Food (Informant: 92.86\%; Children: 97.41\%) and change of Weather (Informant: 88.78\%; Children: 92.03\%) are seen as a major factor for street children.

In order to survive the street children, they need to reside in areas with a special supportive environment and characteristics that do not conflict with their life-style, nor pose threats against their existence. To solve the problems of migration they should know the scheme and services provided by the Government and NGO's. But the study has shown that, only small proportion of children can access Awas Yojna, Ration system, Self Help Program where as out of 600, 425 are not aware about these services. They more or less access only Free education (155) and drinking water from tube-well (425).

According to hypothesis 1 there is significant difference in social status in terms of their living pattern of the children living with the family and without family. The assumption is made on the basis the more number of family member means more heads to earn, thus the family will have better living. The assumption is also made on the basis that the most of the orphan children has no family and other miscellaneous expenses to bear, so they can also lead a better life. However data rejects the hypothesis indicating there is no social status difference between the group, this may be because that more member though indicated more earning head, but also indicate the increase in life support expenditure. Children without family often need to send their earrings to their parents at their native place and orphans are reluctant to earn extra for better living.

According to hypothesis 2 there is significant difference in economic status in terms of their monthly income of the children belonging to nuclear and joint family. The assumption is made on the basis of hypothesis 1 that more members in family mean more earning. The hypothesis 2 is been accepted indicating that children who ever is migrating with family members, have more than one earning members within family irrespective of the family pattern.

According to hypothesis 3 and 4 there is significant difference in economic status in terms of their monthly income of the children belonging to nuclear family, joint family and orphans. The assumption is based on that children with family have more earning member, thus expected that the children with family will have better economic status than the orphan. Thus hypothesis 3 and 4 both are accepted.

According to hypothesis 5 there is no significant difference in motives of migration to Kolkata Street among the children coming from the areas outside Kolkata and West Bengal. The hypothesis is accepted on the assumption that children coming to Kolkata from outside of West Bengal have the clear motive of employment, attraction for metro life, family force or suffering from social environment. However children migrating to Kolkata within the state location have the same motives as mentioned above, but other important motives are of better education, avoid schooling, peer imitation etc.

According to hypothesis 6 there is no significant difference in causal factor of migration among the children living with and without the family. This hypothesis can take the support of hypothesis 5 that when the motives among the children are different, then there will be difference between the casual factors, which has been proved through the rejection of hypothesis 6 .

According to hypothesis 7 the variables are positively correlated, i.e. Street Children is positively. The inter-correlation between Street Children and Migration is positively co-related. It shows that increase in street children indicated increase number of migration into Kolkata Street. It can also be said that the migration can be the root cause of street children at Kolkata. The correlation between the measures of Migration and Poverty rate is also significant, that the people or the children came on the street of Kolkata thorough migration intended to 
live the poverty life because of the trap of vicious circle, so it can be said that there is a positive association between the both. The correlation between Street Children and Poverty is positively. It shows that children who are migrated on the street of Kolkata are having high probability to live life. Thus hypothesis 7 is accepted.

The regression analysis indicates that the factors of migration is directly attributing to the problem of street children at Kolkata, hypothesis 8 is accepted.

The present study can be summarized with the inference that Poverty and the migration are the predictors of the street children at Kolkata. To put check on the street children and develop them into perfect citizens the government need to frame the policies and action to reduce street migration by children. This will need to drop the non-income form of poverty along with material poverty. These children are victims of the socio-economic conjuncture of the country which often leads to the break up of families. Girls either married at a very young age or then abandoned but quickly taken into the prostitution network, are in lesser numbers on the streets than the boys.

In a constant struggle to live, these children have to use any and whatever means possible to survive: begging, stealing, sweeping trains, polishing shoes, etc., threats from the older children, rejection from society, rape, sickness, drugs, and prostitution. With desperate need to keep moving and maintain freedom, they do not even have an inclination to think about their futures. Their day starts on the streets and ends on the same street.

\section{Discussion}

Kolkata has been a cosmopolitan city of India from the days of the British raj. For many years poor people, not only from rural Bengal but also from other provinces and states of India, trickled into it, some of them were attracted by the glitter of the 'second city of the British Empire'. With the independence of India and the partition of Bengal in 1947 the trickle snow-balled into a massive influx of refugees from East Bengal, which went to Pakistan. Thousands of destitute came over to Kolkata and started living in makeshift shanties and in all available vacant public places. Invisible trickles from Bangladesh still continue even after sixty five (65) years of independence. The glitter of Kolkata's urban life has been attracting the poor rural families of neighboring countries or rural areas to migrate for a better livelihood but is disappointed because the city of Kolkata failed to fulfill their aspiration. However, there was no way of return for those poor families.

The Literature review and the findings of this study reveal that these children have different push and pull factors for migration to the streets of Kolkata, such as poverty and ill environment, lack of education and awareness, unemployment are the push factors and prosperity, opportunity and employment are the pull factors .The study corroborates evidence from the literature review (Arabi, khalafalla Ahmed Mohamed, Ali, Wisal Altahir, 2011; Wazed,Soniya,2010; Conticini, Alessandro, Hulme, David 2007; Schimmel, Noam,2006; Joshi, Harish, Visaria, Leela and Bhat, Rajesh, 2006; Tchombe, Therese M, 2002; ) that poverty, assorted family problems including abuse, to work for money, lack of home / family, attraction of the city life are the main causes of migration to the streets of Kolkata. Other noteworthy factors are emerged from the literature review and from the present study are illiterate parents, step parenting, avoiding school, boredom at home, family / parent marriage breakdown, following friends, unjust community structure, restrict education.

This study also indicate that the street of children in Kolkata are strongly associated with a series of socio---cultural and environmental factors that put the children at risk of certain hazards in their daily life. These children are generally excluded from the socio---economic amenities of the community. This similar findings have been cited by Wazed, Soniya,2010; Ezgi, Pehlivanli,2008; UNICEF, 2002(Study on Street Children in Zimbabwe). But the findings of the study also revealed that, they are exposed to neglect and aggressions of various sorts from the family and the outside milieu that pushes them into further exclusion, which is thus time orchestrated by the children themselves in reaction to the aggressions. They thus variably react by getting into a state of depression, running away from school, or from the family, getting involved with gangs or having recourse to substance abuse etc.

Findings from Schimmel (2006) and Association for Development, Delhi (2002) showed that condition of the street children after migration to the streets are vulnerable and they are facing multi dimensional problems. But the current study illustrates that children living with the family are indigent families, who migrated from different areas some of them stay in the recognized slums of Kolkata. But those who could not arrange, had no other alternative than to live in the jhupris raised by them by the sides of railway lines, on the banks of water bodies, under fly-overs, in the alleys adjacent to parks and markets, on the pavements and other open public places in and around the city. The children dwelling in such unrecognized jhupris are considered as street children. This scenario is also applicable for children living without family and orphan. This study shows that, Street children of Kolkata are spread over almost all its 141 municipal wards. However, their concentrations are higher in the areas close to the railway stations and market places, where job opportunities are better like Gariahat market, New market, Shyambazar more, Tollygaunge metro station,Sealdaha station, Ultadanga station, etc. The children do various kinds of work, including rag-picking, begging etc., just to eke 
out their wretched existence. Some of them are often allured to petty crimes, like black-marketing, pickpocketing and drug trafficking. They have lost their childhood. They don't even know how to smile. Perhaps they cannot also dream of a sunny life.

Like Wazed Soniya (2010), researcher also found that street children of Kolkata like other city do not enjoy basic amenities such as health, education, nutrition, and recreation. Study shows that they live in an unhygienic and polluted atmosphere. Their working and living nature puts a lot of strain on their physical and mental conditions. Malnutrition and other diseases are commonly seen in them. They always face harassment by general public, municipality, police, local dada or antisocial. In case of adolescent girls, the cases of insecurity and rape (some times by family member also), kidnapping and assault very frequently happened in streets of Kolkata.

The findings also reveal that the street children of Kolkata are extremely vulnerable due to one or more of the following reasons or circumstances: Some of the children migrated to the city with their parents, while some of them were born on the streets and grew up in open public places. They have no permanent shelter.Some of their infirmities are more or less endemic due to their low caste or social status, unclean family habits and lifestyle, squalid environment, poverty-related disease patterns etc. They are born in families where there is a history of child abuse and serious internal conflicts which are disaster-prone. They are re-located in surroundings in which they are very likely to be exposed to intense and multiple risks to their mental and physical health, such as kidnapping and abduction, child marriage, hazardous labour, sexual abuse, and even prostitution. Moreover, as these children live on pavements around railway and bus stations, in squatters' colonies by the side of railway tracks and canals, they are often victims of road accidents. Also a constant fear of eviction and harassment by the police and the public haunts them. Unsafe drinking water causing gastro-intestinal diseases, undernourishment, squalor, hunger and ill-health, all combine to make a woeful saga of their miseries. Above all, neglect, abandonment, destitution, violence and sexual exploitation make a hell of their existence. Similar findings also seen in the work of Wazed,Soniya (2010), Sing, Dharam et.al. (2008), Joshi, Harish et.al. A good number of the street children were found who belonged to the migrant families in Kolkata and second generation residents in the city . Being totally cut off from the traditional values by which their parents lived in the old village homes, the growing boys and girls living on the streets often succumb to the allure of vices such as pick-pocketing, black-marketing of petty items, drug-trafficking and theft. Addiction to cheap drugs is not also uncommon.

It is very difficult to separate street children from working children, as one class overlaps with the other to a large extent. Many street children are also working children. Most popular job pattern among these children in Kolkata are begging. Most of them do odd jobs as porters, vendors, helping hands in small hotels and wayside restaurants, paper-bag makers and rag-pickers, selling vegetables on the street, selling variety goods like scarf, hairpins, bangles, strawberry (seasonal), agarbati (incense sticks) etc. This similar scenario are seen by Owoaje, Eme t. et.al.(2009); Habib, Farida et.al.(2007) in their study. From the review of literature of present study (Sing, Dharam et.al., 2008; Habib, Farida et.al., 2007; Joshi, Harish et.al., 2006) seen the pattern of occupational hazards among the street children, but the study reveals ,beside this non- hazardous job pattern children also involved in hazardous pattern of job like rag picking, factory worker, helper in construction work, cinema ticket blacking, prostitution in Kolkata in which they face occupational hazards occasionally, scavenging is certainly one of the most serious ones. Those who are involved in the rag and metal picking work, however, spend most of their day-time in picking up used paper, waste plastics, rags, bottles, tin and metal pieces from the street, garbage dumps and bins and in selling them to retailers for recycling. The children do not just fan out and pick whatever they think is saleable (UNCDP report). They are trained to collect a specific item which has been allotted to them. They operate in wellorganized groups which comb selected areas. Thus there are some rag-pickers who pick up only paper and others who pick up just scraps of metal. The nature of their work is most unhygienic and dangerous. While collecting rusted iron pieces, they receive cuts on their hands, making them susceptible to tetanus. Broken glass lying in garbage dumps injures their bare feet. They also face the risk of inhaling poisonous fumes. Carrying heavy loads on their backs adversely affects their height, weight, strength and stamina. Naturally their growth is stunted. Added to these is the temptation to eat left-over or thrown away foods which often leads to serious stomach problems. Moreover, this study pointed out that the average monthly earnings of a child worker in Kolkata is Rs. 250-300/- in garages and small engineering units, Rs.50-100/- in small hotels and restaurants, Rs.90/- in tea stalls and Rs. 90-100/- in sweetmeat shops (Kolkata Plan of Action). Fifty-five percent(55\%) of the working children in Kolkata earn less than Rs. 100/- per month(approximately) and there are many who work just for two meals a day without any cash earnings. The present study revealed, among the respondents a large number of children are engaged in casual labor, domestic helps, helpers in the unorganized sectors, ragpickers, factory workers, hawkers, and milk or newspaper vendors and in other occupations 
However, a recent Supreme Court order prohibiting child labour has thrown some of them out of work, but not all. These children are paid very poor wages for heavy work. Some of street children mostly work as self-employed in the fields of rag-picking, vending, hawking and shoe-shining. Those who do not like to work for money take to begging, pick-pocketing or even stealing.

\section{Protection-cum-Exploitation}

A recent study revealed a very pathetic aspect of the street children's life. The survey shown has that many of them live under the patronage of local "Dada-s" (big brothers) and have to pay them a part of their earning by way of a sort of levy. Apart from them, the police also demand a share out of every child's income. These children have, therefore, to live under tremendous stress. Though their number is small compared to that of working children, they are at a far greater risk of exploitation.

\section{Plight of Street Girls - Additional Exploitation Risks}

The problem is much more acute in the case of adolescent street girls. They are an extremely vulnerable group generally because of the risks that females face in a male-based society, and more specifically because of the strong likelihood of their being kidnapped, abused and ultimately lured into the sex trade. Most of the growing girls living in slums or pavements are in constant danger of being abused. Those in the age-group of 10 to 16 years are prone to sexual abuse by adult men living on the streets or by their male relatives, including brothers and even fathers, at their "homes". Among the families living on the pavements it is common for girls to be abused by male relatives and then forced into prostitution, many times by mother also. Many girls are often married off as soon as they attain puberty. However, in many instances the marriage not last long. Often by the time the girl turned sixteen she could have been married twice or thrice. The children born of broken marriages are naturally abandoned and they swell the ranks of street children.

Sex for survival is common amongst girls who live alone on the streets. They may not necessarily be paid cash, but given some food or clothes or be taken to a movie show as a consideration for sex. The girls offer their services to the local "Dada-s" in return for protection and / or paltry sums of money. Promiscuity without the use of condoms is a high risk behavior, but most of these girls are neither aware of, nor in a position to practice, safe sex.

Social Welfare Activities for the Street and working Children From the early 80 s, some Non Governmental Organizations have come forward to undertake welfare activities among the street and working children. In 1987 the Calcutta NGO Forum for Street and Working Children was established, so that their collective intervention could be more effective and meaningful. They constantly tried to draw the Government's attention to the plight of the street and working children.

Finally, in 1993, both the Government of India and West Bengal State Government decided to extend support to the NGOs for undertaking meaningful programmes for street children, in the fields of education, nutrition, health, skill development and recreation. Besides, UNICEF, ILO and some other funding agencies are also supporting some NGOs in this regard. Moreover, the Government of West Bengal regularly undertakes various street children welfare programme including sports and recreational activities for their all-round development through Kolkata Police, Community Wings(a city-level task force has been established by the Government of West Bengal) which coordinating all these welfare activities, with the active participation of NGOs. In the year 2001, the Kolkata Child Labour Rehabilitation-cum-Welfare Society was formed under the President ship of the Labour Commissioner of West Bengal and this society has recently started to support 40 local NGOs to run forty special schools for child labourers, with the financial assistances of the Government of India.

Today there are nearly 100 NGOs in Calcutta. Most of these NGOs are members of the network called the Calcutta NGO Forum for Street and Working Children and many of them are also linked with the City Level Programme of Action for street and working children (CLPOA). These NGOs provide health care, nutrition, education, and recreation, skill-training and counseling services for street children. There is a strong and urgent need for shelter for the street and working children in the form of half-way homes, drop-in centers and night shelters or dormitories. The main function of these centers would be to provide a space for children to bathe and keep their belongings and to sleep at night. They should also have opportunities for recreation and outings. All this will hopefully help them regain some of their lost childhood.

There are approximately over a100,000 street and working children and socially excluded children in Kolkata Metropolis, dwelling in the squatters' shanties close to railway tracks, market places, pavements and on the banks of sewerage canals. They suffer from lack of proper shelter, food, clothing and family care, the absence of social security, from exploitation, abysmal poverty and malnutrition. They are often lured into labour related to vices such as narcotics-trafficking in exchange for a pittance and sometimes sexual exploitation, particularly adolescent girls. Social, psychological and physical harassment are common occurrences. It is no wonder that when these children become adults many of them may become anti-social, criminals, alcoholics, 
drug-addicts and prostitutes. If these children and young people are to live meaningful lives they need the basic necessities for existence and a flow of information about their rights, about the forces that keep them poor and helpless and about the potential for change. Now they do not know what the future holds for them; they have no hopes or dreams.

\section{Integrated Programme For Street Children, Govt. Of India:-}

This is one of the prestigious projects awarded by ministry of Women and Child Development, Government of India, New Delhi with its counterpart in West Bengal Department of Vagrancy, Purto Bhavan, Government of West Bengal, which has been running successfully to cover 300 children every year. During the said period the success rate was more than $60 \%$ and good number of children mainstreamed in formal schools (More details in the following table). The aim of the project is rehabilitation and formal schooling of the children living in street along the railway lines and canal side by providing bridge courses, special coaching, mid-day meal, supply of educational kits, provision of basic facilities like water, sanitation etc. The children are spread over in the 6 units (Each unit covered 50 children) are popularly known as Resilience Centres. Special attention given to proper counselling of the traumatized children and kids belong to broken families living on destitution and dying of hunger, gross neglect of their nourishment, violating Child Rights and other denial of basic services. $50 \%$ of these children are engaged in hazardous occupation like waste picking, long working hours in tea stalls, leatherwork and other work injurious to their health and growth. The psycho-emotional development and loss of childhood are the key concerned area of their needs.

The project dealt with above issues and reduced various forms of exploitation and helped the parents to earn livelihood from Self-Help Group formation and micro-finance projects, the organisation has been running in collaboration with banks, micro-finance institutions and other financial services.

Vocational training is one of the most important components in the project, which provides training on viable trades like stitching, sewing Dupatta, setting mat, buttonhole, hanky embroidery, fabric painting \& other cutting work related to garments. The project provided raw materials and trainer for the purpose. The organization also studied the market feasibility and scopes of earning their livelihood after the training is concluded. The project also provided contingency for rehabilitating them in the squatter settlements like bamboos, plastics, construction materials etc.

Annual Sports is also organized to encourage sportsmanship, physical fitness and mental alertness which help them regain their childhood and create interest in educational activities.

\section{Limitation}

This study is limited by 600 samples of 12 Wards in Kolkata city. The generalization of the findings in the study of other areas should be made cautiously. Other limitations are follows:

The major research limitation of this study was shortage of time. For deeply understanding the causal factors for Migration of street children in Kolkata are required a large sample for which span of study time is not enough.

To understand the scenario of push and pull factors for migration, it is essential to conduct the study in the various states, outside of Kolkata from where childrens are migrated to Kolkata. This procedures is much more time and cost consuming, due to this researcher is unable to do it.

These children moved from one place to another in search for food, income etc. It is difficult to communicate with them about research objectives and goals.

Because of these limitation factors, I had to be flexible and my approach according to the needs of the respondents and research.

\section{Conclusion}

Migration of children to city is a Global phenomenon. Migration of children to streets of Kolkata is either from outside of Kolkata or from outside of West Bengal. There is no significant differences with the motives for migration in both cases though in the present study the children migrated from outside of Kolkata are slightly greater than those migrated from outside of West Bengal. This may be due to proximity of the city to the migrants from outside of Kolkata. Children living with the family are migrated in greater number than those living without family. Males are migrated more than the females. The pre dominant causes for migration are poverty, assorted family problems, attraction to city life, family breakdown, peer pressure etc. The root cause being a search for a better living of which they are again deprived due to their ignorance of different Govt, Semi-Govt. or NGO's help Program and partly due to neglect from the authorities concerned.

In the present study, it has shown that children have taken some survival strategy for livelihood after migrated to the streets of Kolkata. Survival means obtaining food, clothing and shelter, and protecting themselves against violence and other forms of abuse which depends on: 
Personal strengths: The child's resourcefulness (the ability to solve problems quickly and efficiently with available resources), and resilience (the ability to recover from shock, depression, and other difficult circumstances) determine his/ her survival. Resourcefulness and resilience would depend upon the child's creativity, hard work, intelligence and concern for one another.

The peer group: Peers are individuals who share common interests and needs. Peer groups tend to be homogeneous in age and gender. The peer group has a strong influence on street children because of the child's need for acceptance, belonging and protection. The group often determines the process of change, socialization and development among street children by providing emotional and material support. Street children often help in one another's survival. They often join together to form emotional and material support networks. The networks can range from a simple circle of friends to an organized, business network. Experienced street children teach new comers how to survive. Members of the group share food, clothing, shelter, information and psychoactive substances.

Chance factors: An important thing that determines the mode of survival is the people whom the child meets on the first day away from home, whether it is a group of car washers or drug traffickers. Being new to the situation he or she does not know that there are other ways of surviving on the street.

Exploiters: Street children may have to do many unhealthy or dangerous things to survive. Other street children, the police, and the adults who run the sex and drug trades may easily victimize them.

Other support mechanisms among street children: These mechanisms could be related to trade or activities in the streets of Kolkata and tend to be hierarchical. For example, there may be a leader and a spokesperson. The roles of group members can vary depending on their strengths and weaknesses. The members tend to protect each other in the face of gang wars, police arrests or other risky situations.

As a child labor: Most of the street children are in economic activities through various types of jobs for mere survival. The nature and extent of child labor differ from region to region, depending on the socioeconomic condition of a society in which the children live. It is very difficult to separate street children from working children, as one class overlaps with the other to a large extent. Most of them do odd jobs and work as self-employed, like:Worker in eatables and tea stalls, Begging and/ or sweeping, Selling newspapers, magazines, Shoe shining ,Rag pickers, Coolie in railway station, Selling eatables, Selling small items like key chains, toys, pens, torches, stickers, etc.,Car cleaning

Selling tobacco and allied products, Pickpockets / stealing, Commercial sex workers (all females), Working in parking areas, Selling of charas and ganja ,

Working in automobile garages, Working in hotels, Vendors, Maid servant,etc.

In this situation one of the respondents said that: "My father had a heart attack two years ago. So, he cannot work now. Doctor said he needs an operation for his treatment. After that I and my elder sister started to work and then my mother also joined in a local family as a maid servant. Now our income is the only source of our family substance".

It becomes ever clearer that solutions for the problem of streetism consist in addressing the causes of the migration to the street. Since street children are an urban phenomenon, urban poverty must be targeted. Rural poverty causes the rural populations to move to urban areas in the hope for employment and a better future. But the unexpected challenges of city-life enhance the breakdown of many families. Thus to prevent rural urban migration, rural life has to be made more attractive. Government Should be adopt remedial measures in this direction. At state level the government has to create conditions

(Democracy, transparency) and provide for employment and social safety to break the poverty trap. NGOs herewith have a role as advocates to ensure government's accountability. Greater coordination between agencies working with street children would prevent more children falling through the net. A consortium of street children organizations would constitute a powerful pressure group for policies on poverty alleviation and for legislative and educational changes (in front of national and international bodies). Networking is a means also to control accountability and to prevent corruption 280 . Above all it offers a

chance for NGOs to work more efficiently and effectively, but this has not become a common practice yet.

Poverty of street children needs to be understood as a violation of basic human right, above all in the sense of being socially excluded and discriminated against. The human rights concept is helpful because it defines neglect as a human rights violation. For street children, having rights above all means being entitled to respect and dignity. Human rights are a tool to formulate basic needs into rights and duties. Human rights can be an effective long-term tool for solving the situation of street children, firstly because they address the various dimensions of poverty and social exclusion. Secondly because they hold states accountable for the promotion, protection and fulfillment of basic human rights for street children. This accountability towards basic human rights can be a tool for breaking the poverty cycle.

In this situation the government should take immediate steps to identify the orphans who work on streets, railway stations, abused children, street children etc. on a priority basis and must try to accommodate 
them in orphanage homes financed by union or state government or NGOs funded by foreign agencies. Rather than trying to help children off the street, and assuming that economic growth and reduced income poverty will stem the flow of new children to the street, it suggests that policies to reduce street migration should focus on reducing the abuse of, and violence against children.

To stop migration of children to the streets of urban areas or Kolkata there are some ways and means may be focused:

Education: Education is the single most powerful way to bring street children back into society and help them build a future for themselves. Adequate infrastructural facilities, trained, willing and committed teachers and improvement of the contents of subjects taught so as to make it interesting, are some approaches that could be followed to make the education "child-friendly'." Small teams of social workers or NGOs can help establish a good environment for street children to attend school. A practical solution might be that an employer who has employed child labor may also open a school for their education. A street educator might also have to step in and persuade the child to go to school. "The aim is to re-create, at least in part, a family atmosphere where activities can be carried out together - work, study, house chores, sports and other forms of recreation."'If the objective of education for all is to be achieved, the formal education system needs to be modified. Universalization of education is one of the most important remedies to deal with the problems of street-children. "But this program should be linked with anti-poverty schemes so that the parents of poor families may send their children to schools in return get cash subsidy to partly compensate for opportunity costs." Because the best way to help save a child " is to achieve reintegration of the child or adolescent into the family and the wider community through education and practical training."

Non-Governmental Organizations (NGO's): Non-Government Organizations (NGOs) are spread across countries, focused primarily in larger cities, sharing a common interest. All have health and nutrition components, non-formal education, vocational training, recreational facilities and some have counseling and saving schemes. The NGOs have done very good work, but it has become difficult for them to find adequate funds and committed people for their activities. In 1987, Michel Gregoire discovered the plight of El Alto, Bolivia's street children. On his initiative, ENDA-Bolivia, a non-government organization, was set up with a dual plan: to help actual and potential street children escape from drug abuse and to create conditions favorable for their re-entry into community life (UNESCO).If this types of variety program continues today all over places particularly aimed at working with children and teens - street vendors, shoeshine boys or employees in small shops or stores - children who often work more than twelve hours a day for an average wage of 200-250 rupees a month. Children of the street in the strict sense, that is, those children who have broken all family ties, who have no economic activity, formal or informal (as street vendors or the like), but who survive only by illegal means (theft, etc.), take drugs, and live in gangs by night, street educators create homes for these children under the condition that they do not bring sex, theft and drugs into the houses. Rather, they participate in community activities. In Puebla, Mexico, the JUCONI project has aimed "to offer young people working or living in the streets, or who run a significant risk of doing either, the possibility of improving their living conditions" (UNESCO). As in so many other Third World countries, the resources available to the government departments are inadequate when compared with the needs. The role of these NGOs is essential.

Human Rights Groups: The rights of many children have been violated for too long. Human rights groups protest against state inaction on street children, against covert and approved state killings, and against the larger socioeconomic system. The issue became worse under military rule when a plan was formed to deal with abandoned children. "The notorious Assistance Service to Minors created correctional facilities. These facilities were intended to be frightening "branches of hell" (UNESCO). Human rights activists were repulsed by this operation and in increasing numbers, began to aide children in prison, police centers, and on the streets. They worked at alleviating the worst hardships suffered by the children and adolescents. "Human Rights activists point to a fundamental achievement - a change in the law, by which they are willing to live or die. Willingness to trust the rule of law continues to drive human rights activists and marks a change in Brazilian and many Latin American societies. "The change moved attention from needs to rights, as entitling them to the resources required. Children are said to have three sets of rights: protection, provision, and participation"(Clearly Edward;2007). People are trying to get children the correct rights and efforts are being made to re-unite child with their families. Human rights activists are also pushing to support children who want to stay with their families. Since their families are poor, the children are labeled as orphans, because no one can take care of them. But that is not true; because being an orphan generally means that your parents do not want you or have left you. This is not the case, this ignorance concerning child-family relations not only represents an obsolete welfare tradition but flouts the UN Convention on the Rights of the Child and many national laws which acknowledge children's right to live with their families, and regard long-term institutionalization as an exception to be used only in severe cases of neglect or abuse, and in emergencies.

Protecting Children: Many governments, nongovernmental organizations, and members of civil society around the world have increased their attention on homeless and street children as the number of this 
disenfranchised population continues to grow dramatically. Nonetheless, more action is necessary. Most importantly, as a result of adverse economic conditions in many countries, an international plan to provide basic housing needs to be developed.

In 1992, the United Nations issued a Resolution on the Plight of Street Children, expressing concern over the emergence and marginalization of street children, and the acts of violence against them. The Resolution called for international cooperation to address the needs of homeless children and for enforcement of international child rights laws. European nations that have taken effective steps toward combating homelessness include Belgium, Finland, the Netherlands, Portugal, and Spain . In many countries, governments have included a right to housing in the national constitution. The Finnish devised a plan in 1987 including housebuilding, social welfare, health care service, and a duty to provide a decent home for every homeless person. The number of homeless people in Finland was cut in half after 10 years. However, the major problem with State programs is that children often reject the alternative assistance offered by the State.

On a local and regional level in India, initiatives have been taken to assist street children, often through shelters. Many shelters have programs designed to provide safety, healthcare, counseling, education, vocational training, legal aid, and other social services. Some shelters also provide regular individual contact, offering much-needed love and care.

Many NGOs have been founded with mission to improve the plight of homeless adults and youth. Casa Alianza, active in Mexico and Central America;

Child Hope UK working with local groups worldwide; Butterflies, based in New Delhi, India; and, Street Kids International, a Canadian-based organization, all focus specifically on street children. Prayas Juvenile Aid Centre (JAC) Society, based in Delhi, India, pioneered the first intensive study on Homeless children ever conducted; they have also set up numerous shelters providing basic security, food, and clothing for more than 50,000 homeless people in Greater Delhi.

As stated in the introduction, given the absence of previous studies in this area, it was anticipated that difficulties would likely reach the street children. The magnitude of the problem is still unknown and by drawing out a random sample from an unknown/hidden population can prove very challenging.

\section{Reference}

[1]. Abdel- Nabi, A. Media Handling of the Problem of Child Vagrancy in Egypt. Institute of Childhood Studies, Ain Shams University, 1994.

[2]. Abu, Al-Nasr, M. The Problem of Street Children in Cairo and Giza. A Paper presented to The Second Scientific Conference in Social Work, Helwan University, 1992

[3]. Afsar, R. (2000) Rural-Urban Migration in Bangladesh: Causes, Consequences and Challenges. Dhaka, The University Press Limited.

[4]. Afsar, R. (2003) Internal migration and the development nexus: the case of Bangladesh.

[5]. Agrawal, Reshmi. "We Can All Help." Street Children. Delhi, India: Shipra Publications, 1999. 143-168.

[6]. Agarwal,Reshmi; Street Children: A Socio Psychological Study; Shipra Publication,India 2003.

[7]. Ahmed, S. and A. M. Adeeb. (1998). Methods and Techniques of Street Education and Substance Abuse Prevention Among Street Children. Dhaka: Aparajeyo- Bangladesh \& Childhope-Asia.

[8]. Ahmed, S. and Jasimuddin, S. M. (1996) Migration of Children to Dhaka City. Thoughts on Economics, Vol. 6(1), pp. 49 -63.

[9]. Al-Amal Village Society. A Report on the Activities and Programs of

[10]. Al -Amal Village Society, Cairo, 2000.

[11]. Alessandro Conticini, David Hulme in "Escaping Violence, Seeking Freedom: Why Children in Bangladesh Migrate to the Street";An E.S.R.C(Economical and Social Research Counsil);Global Poverty Research Group; http://www.gprg.org./pp.1-46 (2007)

[12]. Ali, Dr. Mehdi (Regional Representative for the Middle East and North Africa) RAPID SITUATION ASSESSMENT STREET CHILDREN OF CAIRO \& ALEXANDRIA, 2002.

[13]. Altanis, P., Goddard, J. "Street Children in Contemporary Greece”, Children \& Society, 2004, Vol.18: 299-311.

[14]. Ancestry.com: Thirteen Reasons Our Ancestors Migrated

[15]. http://www.ancestry.com/learn/library/article.aspx?article=1436

[16]. Anglia Campus: Migration http://www.angliacampus.com/public/sec/geog/migrate/index.htm

[17]. Aptekar, Lewis and Heinonen. "Methodological Implications of Contextual Diversity in Research on Street Children." Children, Youth and Environments 13(1), Spring 2003. Retrieved [14/8/2007] from http://colorado.edu/journals/cye.

[18]. Arabi, Khalafalla Ahmed Mohamed; University of Bakht Erruda - Sudan Wisal Altahir Ali,University of Khartoum in Factors Affect Homelessness Among Street Children in Khartoum State(2011) Journal of Business Studies Quarterly 2011, Vol. 2, No. 2, pp. 98-106 ISSN 2152-1034; jbsq.org.

[19]. ARISE (2001) Baseline Survey of Street Children in Six Divisional Cities of Bangladesh. Dhaka, Department of Social Services, Ministry of Social Welfare, Government of Bangladesh.

[20]. Association for Development, Delhi (2002) in "A Study on the problems of street and working children living at railway station in Delhi”; DCWC Research Bulletin; Vol. VIII, Issue 4, October-december 2004, New Delhi: AFD. 9p.

[21]. Baybuga, Media Subasi; Celik, Sevilay Senol. (2004) "The level of knowledge and views of the street children/youth about AIDS in Turkey”. International Journal of Nursing Studies vol. 41 issue 6 August, 2004. p. 591-597.

[22]. Bednarz, Dr.Sarah W.;Human Migration Guide (6-8) 2005, National Geographic Society; Human Geography.

[23]. Blanchet, T. (1996) Lost Innocence, Stolen Childhoods. Dhaka, The University Press Limited.

[24]. BSAF. (1998). Cases Studies of 10 Tokai Children. Dhaka: Bangladeshi Shishu Adikar Forum

[25]. Bustamante, D., 'Family Structure Problems, Child Mistreatment, street Children, and Drug Use', cited in Schraeder, A. et al, Prevention of Street Migration (1999), p. 27 [online], available at 
[26]. http://www.streetchildren.org.uk/reports/CSC.UCC $\% 20$ Prevention $\% 20$ of $\% 20$ Street $\% 20$ Migration $\% 20$ Pack.pdf [Accessed 03 March 2011]

[27]. Caritas-Egypt. Dealing with the Problem of Street Children. A Paper presented to the ACCD Workshop on "Confronting the Problem of Street Children in the Arab World", ACCD, Cairo, 1999.

[28]. Conticini, Alessandro and Hulme, David. (2006). Escaping Violence, Seeking Freedom: Why children in Bangladesh migrate to the street. PRCPB Working Paper No. 10.

[29]. Children of the World Human Rights, EDMH (2009), Survey on "Children in Street Situation" in Juba, [Online], available at

[30]. http://www.gurtong.net/LinkClick.aspx? fileticket=tY\%2Fu1r63giE\%3D\&tabid=124 [accessed 13th January 2011]

[31]. CRC Coalition. NGOs Report on the Rights of the Child in Egypt. Attala Publishing House, Alexandria, 2000.

[32]. CSC. (2001). Violence Against Children Within the Family. London: Consortium for Street Children.

[33]. CSISS Classics: Ernest George Ravenstein-The Laws of Migration, 1885 http://www.csiss.org/classics/content/90.

[34]. Deshingkar, P. and Grimm, S. (2005) Internal Migration and Development: A Global Perspective. International Organization for Migration, Geneva

[35]. Duyan, Veli, :"Relationships between the Socio-demographic and Family Characteristics, Street Life Experiences and the Hopelessness of Street Children", Childhood: 2005,A Global Journal of Child Research, v12 n4 p445-459 (November 2005 12: 445-459).

[36]. Drain, N. (2010) 'Street children as unaccompanied minors with specialized needs: deserving recognition as a particular social group', New England Law Review, Summer.

[37]. El-Gindy, A. Children in Difficult Social Circumstances. National Council for Motherhood And Childhood, Cairo, 1997.

[38]. El-Kateb, E. Street Children. Documents of the Conference "Children in Difficult Circumstances", Ahebaa El-Toufoula NGO, April 1998, pp.141-151.

[39]. Ennew, J. et al, (1989), The Next Generation, London: Zed Books; Hecht, T. (1998), At Home in the Street, Cambridge: Cambridge University Press; Green, D. (1998), Hidden Lives, London: Cassell.

[40]. General Social Defense Department. The Programs of the Ministry of Social Affairs in Dealing with Children Exposed to Delinquency. Unpublished Report, 2000.

[41]. Habib, Farida; Nayaib, Ramla; Salma, Khan, Kehkashan;

[42]. Jamal, Asra; Cheema, Anila Aman and Imam, Nausheen: Occupational Health Hazards Among Street Children; Department of Community Health Sciences, Karachi Medical and Dental College, Karachi 92-95, e:/biomedica vol.23 jul. - dec. 2007/bio-16 (a).

[43]. Hasina, S. (1989). Ora Tokai Keno. Dhaka: United Nations Children's Found.

[44]. Hussein, N. The Phenomenon of street Children: A Field-research in Greater Cairo. Unpublished PhD Dissertation, Ain Shams University, 1998.

[45]. Ibid, p. 63 .

[46]. Ibid, p. 82 .

[47]. ILO/IPEC (2000), In---depth Analysis of the situation of working street children in St Petersburg, [Online], available at http://www.csmonitor.com/2003/0502/p07s01---woeu.html [accessed 03 March 2011]

[48]. International Convention on the Rights of the Child. (1989). Adopted by the United Nations General Assembly Resolution 44/25 of 20 November, 1989 and entering into force September 2, 1990. Retrieved August 14, 2007, from http://www.unhchr.org

[49]. International Council on Social Welfare. (2006). Statement to United Nations Commission for Social Development, 44th Session, New York, February 8-17. Retrieved August 14, 2007, from http://www.icsw.org/un/un.htm.

[50]. IPER (1990) Situational Analysis of Street Children in the City of Calcutta. UNICEF, Ministry of Welfare, Calcutta.

[51]. Joshi, Harish, Visaria, Leela and Bhat, Rajesh (2006) in "Children without Childhood, Ahmedabad". . Ahmedabad : Ahmedabad Study Action Group, 2006. vii, 63 p. : ill. ; 27 cm. (Bookmark: http://trove.nla.gov.au/version/172177139).

[52]. Kacker, L, et al (2007), Study on Child Abuse: India 2007, p 38---39. Ministry of Women and Child Development, Government of India, [Online] Available at: http://wcd.nic.in/childabuse.pdf.

[53]. Koraim, A. The Dimensions of the Problem of Street Boys. Documents of the Conference "Children in Difficult Social Circumstances", Ahebaa El-Toufoula NGO, Cairo, 1998.

[54]. Kurtz, P. et al. Problems of Homeless Youth: Empirical Findings and Human Service Issues. In

[55]. "Social Work", (36), 1991, pp.309-314.

[56]. Lee, E. (1966) A Theory of Migration. Demography, Vol. 3, pp. 47-57.

[57]. Lewis, G. (1982) Human migration: a geographical perspective. London, Croom Helm.

[58]. Lusk, M., Peralta, F., \& Vest, G. (1989). Street children of Juarez: A field study. International Social Work, 32, $243-245$.

[59]. Lusk, M., Boise State University; Rizzini, I. , The University of Santa Ursula Rio de Janeiro, Brazil, 'Children in the Streets:

[60]. Latin America's Lost Generation'; Children and Youth Services Review, Vol. 17, No. 3, pp. $391410,1995$.

[61]. Mangalam,J.J: Human Migration, University of Kentucky Press, 1968.

[62]. Masud Ali, A. K. M., A. K. M. Mustaque Ali, and R. Sarkar. (1997). Misplaced Childhood: A Short Study on the Street Child Prostitutes in Dhaka City. Dhaka: INCIDIN.

[63]. Massey D.S, Arango J, Hugo G, Kouaouci A, Pellegrino A, Taylor JE. 1993. Theories of international migration: A review and appraisal. Population and Development Review, 19 (3), pp.431-66.

[64]. Mexico Child Link Trust, 'Street children -What are Street Children?' available at http://www.mexico-child link.org/street-children-definition- statistics.htm

[65]. Migrations Resources, U.S. Census Bureau http://www.census.gov/

[66]. Migration Information Source http://www.migrationinformation.org/

[67]. www.nationalgeographic.com/xpeditions (C) 2005 National Geographic Society. All rights reserved.

[68]. Minujin, A., J. Vandemoortele, and E. Delamonica. (2002). 'Economic Growth, Poverty and Children'. Environment and Urbanization 14(2):23-44.

[69]. Narayan, D. and Petesch, P. (2002) Voices of the Poor: From Many Lands. Oxford/ Washington DC, Oxford University Press/ The World Bank.

[70]. ODCCP. Drug Abuse: Rapid Situation Assessment and Responses. ODCCP Studies on Drugs and Crimes. United Nations, 1999.

[71]. Owoaje, Eme T., Adebiyi, A.O. and Asuzu, M.C., Socio-demographic Characteristics of Street children in Rural Communities undergoing Urbanization (Department of Community Medicine, College of Medicine, University of Ibadan) Annals of Ibadan Postgraduate Medicine. Vol. 7 No. 1 June, 2009. pp.10-15

[72]. Overview, cited in UNICEF (2005), Regional Assessment on Violence against children in East and the Pacific Region p. 162 [online], available at: http://www.violencestudy.org /IMG/pdf/EAP_2005_Assessment_on_VaC.pdf [Accessed 26 July 09]. 
[73]. Parwell, Mike.; Population movements and the Third World, 1993; Routledge (London and New York) publishers.

[74]. Pehlivanl, Ezgi . A Sociological Profile of Street Children in Ankara; (The Graduate School of Social Sciences of Middle East Teschnical University; M.A. Department of Sociology);January,2007.

[75]. Population Reference Bureau http://www.prb.org/Content/NavigationMenu/PRB/Educators/Human-Population/Migration1.htm

[76]. Project Concern. Rapid assessment of street children in Lusaka: fountain of hope, Flame Jesus Cares Ministry. Lazarus. Zambia; 2002.

[77]. Railway Children, 'Our work in India', [online]. Available at http://www.railwaychildren.org.uk [Accessed 11 July 2011]

[78]. Ray, Dr. Patricia; Davey, Corinne; Nolan, Paul: Still on the street - still short of rights. Text Plan and Consortium for Street Children British Library Cataloguing in Public Data.

[79]. RevisionNotes.Co.UK: Migration http://www.revision-notes.co.uk/revision/171.html

[80]. Richter, L.M (1991), Street Children in South Africa---General theoretical introduction: Society,family and childhood, Part 1 of a paper presented at the First National Workshop of Street-Wise, April 1990. Johannesburg.

[81]. Salaam Baalak Trust, 'Health Program' [online]. Available at:http://www.salaambaalaktrust.com/health.asp, [Accessed 2011].

[82]. Sedik, A. Experiences with the Problem of Street Children in Egypt. Center for Child Protection and Rights. Cairo, 1995.

[83]. Schimmel, N. (2006). Freedom and autonomy of street children. International Journal of Children's Rights, 14(3), 211-233.

[84]. Singh, Dharam; Sareen, Nishtha; Ojha, Abhishek and Sareen, Devendra : "Street Children of Udaipur: Demographic Profile and Future Prospects" (Department of Pediatrics, R.N.T. Medical College, Udaipur Rajasthan, India; E-mail: $<$ nishtha_sareen@yahoo.com) Stud Tribes Tribals, 6(2): pp. 135-139 (2008).

[85]. Smithsonian Institution: Migrations in History http://smithsonianeducation.org/migrations/start.html

[86]. Stephenson, Svetlana (2002) reported on, "Crossing the line: vagrancy, homelessness and social displacement in Russia" London, Ashgate.

[87]. Stephenson, Svetlana (2002) Child labor in the Russian federation : working paper. Geneva: International Labor Organization. http ://www.ilo.org/dyn/declaries/DECLARATIONWEB.DOWNLOAD_BLOB?VAR_DOCUMENTID=1620

[88]. STREET CHILDREN: A Mapping \& Gapping Review of the Literature 2000 to 2010 ;Consortium for Street Children

[89]. Tchombe, Therese M., Mopoi Nuwanyakpa, and Tarpeh Etmonia. "Street Children in Cameroon : Problems and Perspectives" . Journals of Psychology in Africa 11, no. 2 (2001): 101-25.

[90]. The General Egyptian Association for Child Protection. Care for Street Children in Alexandria. Unpublished Report in Arabic, Alexandria, 1999.

[91]. The Ministry of Social Affairs. Social Defense in Lines. Unpublished Report, 1999.

[92]. The Subculture of Street Children. Documents of the Conference "Children in Difficult Social Circumstances", Ahebaa El-Toufoula NGO, Cairo, 1998.

[93]. Thomas de Benitez, S. (2007). State of the World's Street Children Violence. Consortium for Street Children. US State Department, Trafficking in Persons report 2010, p137

[94]. Thomas de Benitez, S., (2007), State of the World's Street Children Violence, p. 64, [online], available at http://www.streetchildren.org.uk/reports/State\%20of\%20the\%20World's\%20Street\%20Children- Violence.pdf. pp. $65-66$

[95]. UN, 1998, p. 343; Todaro, 1980a, p. 169

[96]. UNICEF. (1985). Borrador del plan para un programa regional de niflos abandonados y del lacalle [Worksheet for the Regional Operating Plan forAbandoned and Street Children]. Bogotd: United Nations Children's Fund.

[97]. UNICEF. (1986). Children in especially difficult circumstances: Supporting annex, exploitation of working and street children. New York: United Nations Children's Fund.

[98]. UNICEF. (1990, September). Children and development in the 1990s: A UATICEF sourcebook. Proceedings of the World Summit for Children. New York: United Nations Children's Fund.

[99]. UNICEF (2002), A survey on street children in Zimbabwe, [Online], available at http://www.unicef.org/evaldatabase/files/ZIM_01$-805 . p d f$

[100]. UNICEF (2002), State of the World's Children 2003, p.37. accessed on 1st March 2011]

[101]. UNICEF (2003), The Situation of Families and Children Affected by HIV/AIDS in Vietnam.

[102]. UNICEF (2005), State of the World's Children : Excluded and Invisible, pp. 40-1.

[103]. UNICEF. 2006. The State of the World's Children. UNICEF: New York.

[104]. UNICEF; Drane, 2010, citing statistics quoted in a 2000 paper by Casa Alianza - a CSO advocating for street children's rights.

[105]. United Nations Office for Drug Control and Crime Prevention UNODCCP (2001), Rapid situation assessment of street children in Cairo and Alexandria, [Online], available at http://www.unodc.org/pdf/youthnet/egyptstreetchildrenreport.pdf .

[106]. Veale, A. and G. Dona (2003) 'Street Children and political Violence : a socio-demographic analysis of street children in Rwanda', Child Abuse \& Neglect 27(3): 253-69, March.

[107]. Wazed, Soniya(Institute of Applied Social Studies, University of Birmingham, U.K. "MIGRATION AND SRETT CHILDREN IN BANGLADESH", OIDA International Journal of Sustainable Development 02:01(2010);(pages:35-42).

[108]. Wikipedia, 'Street Children' [online],available at http://en.wikipedia.org/wiki/Street_children [accessed 28th February 2009]

[109]. World Vision Georgia (2007), 'Street Children and Child Labour in Tbilisi' [online] Available at

[110]. http://meero.worldvision.org/docs/55.pdf [Accessed 28th February 2011]

[111]. WHO. The Rapid Assessment and Response Guide on Psychoactive Substance Use and Especially Vulnerable Young People. Geneva, 1998.

[112]. WHO/PSA. A One Way Street? Program on Psychoactive Substance Use Among Street Children. Geneva, 1993.

[113]. World Health Organization. Working with street children.WHO/MSD/MDP/00.14; 1995.

[114]. www.streetchildren.org

[115]. www.unicef.org

[116]. www.mkombozi.org

[117]. www.abwv.org.

[118]. www.unicef.org/evaldatabase/files/ZIM 01-805.pdf · PDF file.

[119]. www.childrenofbahia.com/childpoverty.htm.

[120]. Zuberi, F. (2005), Assessment Of Violence Against Children In The Eastern And Southern Africa region : Result on an Initial Desk Review for the UN Secretary General's Study on Violence against Children, p.54 [online] Available at http://www.violencestudy.org/IMG/pdf/Desk_Review---3.pdf [Accessed 01 August 09]. 


\section{Annexure - I}

\section{Stakeholder's (Administration and NGO) Engagement Process:}

There was an active involvement of the major stakeholders from the beginning through the implementation of the study to drawing major conclusions as a means of getting their commitment to the process and the outcomes. In fact the major stakeholders were identified and were regularly informed and consulted as the study progressed. Among the major stakeholders were the following:

1. Kolkata Police (Community Wings),

2. Hope Kolkata Foundation,

3. Women InterLinked Foundation (WIF)

4. Kolkata Municipality,

5. Child in Need Institute (CINI)

6. Railway Police, Sealdaha,

7. Urjo.

The questionnaire was sent to them for review and scrutiny .Suggestions, if any, were incorporated to make sure that all their concerns were taken into consideration before it is approved. During the study, the stakeholders were convened to working sessions during which they were informed of the process, progress of the study and on the preliminary results. It is in this light that some of the members were convened to a final briefing where the results of the study will be presented for their information and feedback.

\section{Projects for Street children in India}

- Rehabilitation Social Development Economic Self Sufficiency Of Rag Pickers (RSDESS)

- Kolkata National Child Labour Project (KNCLP)

- Integrated Programme for Street Children (GOI)

- Trickle Up Program

- $\quad$ Sponsorship Programme For Destitute Girls (AIDOS)

- Kolkata Environment Improvement Project (KEIP)

- Shikshalaya Prakalpa (SSA)

- Shikshalaya Prakalpa (MID DAY MEAL)

- Kolkata Urban Services For The Poor (KUSP)

- Future Possibilities.

\section{Annexure - Ii}

In the present study structured schedule for Street children were use for data collection. Because of illiteracy or semi- literacy level of respondents and guardian or caregiver of informant, they unable fill-up the questionnaire .But in Schedule type they need not to do this, researcher herself filled the schedule through collecting information directly from respondents. In comparing to the Questionnaire, benefits of the Structured Schedule are mention below :

1. Questionnaire can be sent via mail but schedule is done only Personally

2. Questionnaire is cheaper method than schedule (for schedule you have to move everywhere)

3. Questionnaire can be returned without answering all the questions but, in schedule, enumerator ensures the filling all the questions.

4. Questionnaire can be filled by anyone but schedule is always

filled by enumerator.

5. Respondent should be literate \& co-operative in Questionnaire but schedule can be filled by illiterate.

6. Risk of incomplete \& wrong information is more in Questionnaire.

7. Physical appearance of Questionnaire has to be attractive but not such case is necessary with schedule.

8. Success of Questionnaire depends on its design but in case of Schedule it depends on honesty \& competency of Enumerator.

\section{Recommendations}

In view of all of the above, the following recommendations can be made:

1. Policy makers must be sensitized to the issue of children in street situations and the societal hazards to which they are exposed. The children on the streets of Kolkata need to be given particular attention by the concerned authorities because they are at risk of exposure to various societal hazards.

2 Given the low level of knowledge on hazards (such as HIV/AIDS, early pregnancies, abortion, substance abuse, school dropout, child abuse and related rights etc.), assistance program should include special activities aimed at informing and educating street children on these hazards properly. 
3. Integrated programs must include professional orientation to develop and strengthened the children's professional aspirations. This will motivate them to pursue their studies and make the necessary effort to stay on track.

4. There is a need to sensitize the children on the availability of the child support services available and on the rights of the child. Given the relatively low knowledge of the children on which institutions to turn to in case of problems, within any assistance program, there should be included campaigns to aware them on possible sources of assistance. The program should foresee home visits as a means of ensuring that the children are not being maltreated and that their integration/reintegration is effective.

5. All institutions and organizations potentially concerned by the street children phenomenon must develop linkages and work in networks to facilitate referral of services. Building bridges between child support organizations and the health service is especially important.

6. A multi criteria evaluation, which takes into consideration the child's level of precariousness as well as his/ her potential of personal development, must guide the selection process for assistance programs. This will include the following:

Criteria 1: Child above 15 years old, not going to school and not working.

Criteria 2: Child below 16 years old and is working for economic reasons even if going to school.

Criteria 3: Attending school but chronically absent from school for unjustified reasons.

7. Given the importance of the role of parents in the child's up-bringing, any child support program must be accompanied by a component to strengthen the families capacity for better up -bringing of their children. States Parties shall ensure that a child shall not be separated from his or her parents against their will.

8. Advocacy has to be intensified to ensure the effective implementation of the

Legislature in the domain of child labor and other child related abuses.

9. Further studies should be made to identify and evaluate the institutional

capacity of local bodies, public/private that can help out with the re integration of these children into the society.

10. Given that most of the children were either in primary school or were primary school drop-outs, the interventions of support programs should concentrate mainly in the primary school. Special efforts should be made to keep these children in school where not only do they run less risk of getting into trouble, but also stand to benefit by their personal intellectual development that open up better horizons for them in the future. 